Portland State University

PDXScholar

1975

\title{
A Methodology for Evaluating the Efficacy of the Placement Procedures of The Dalles Community Attention Home
}

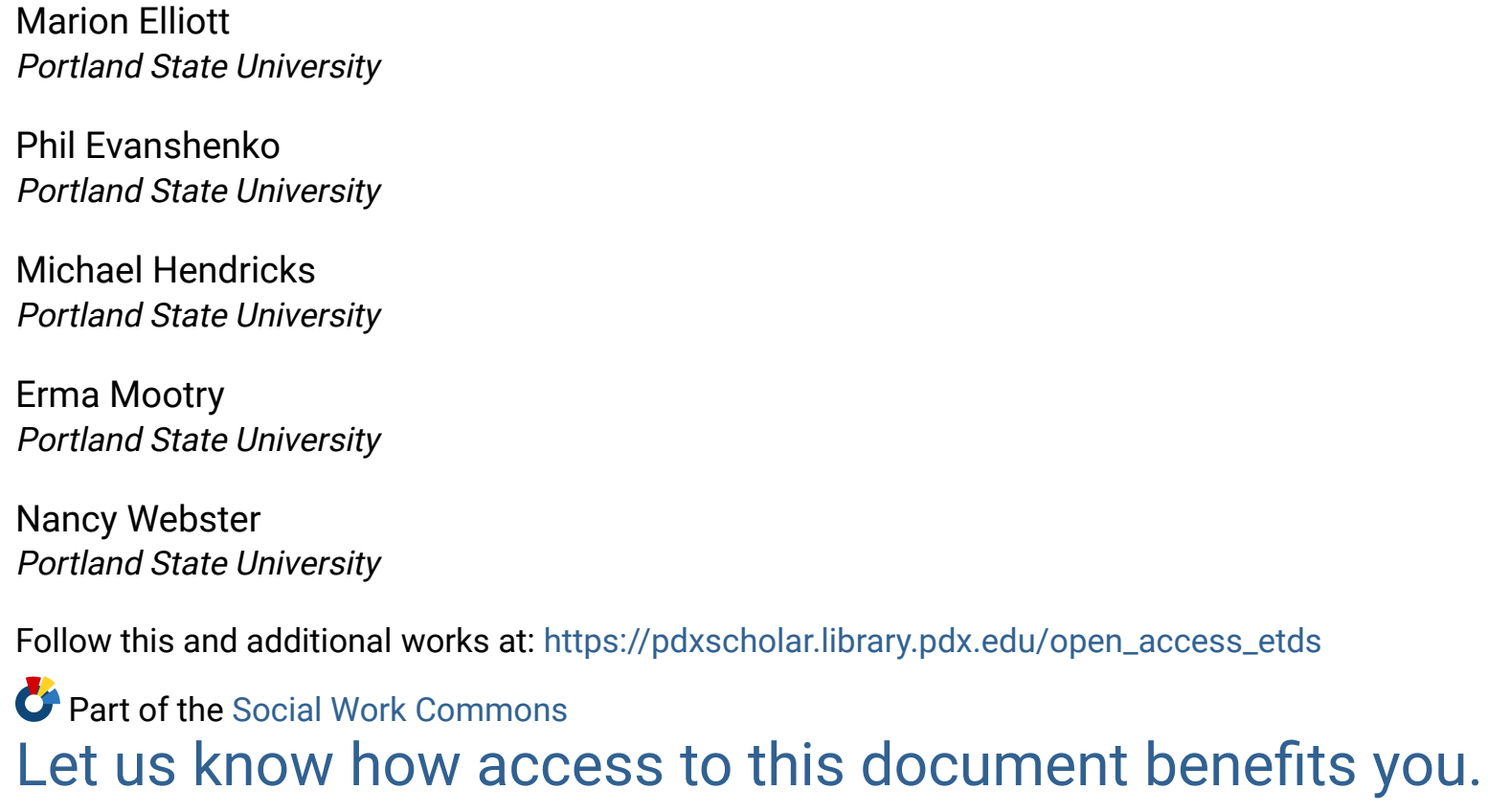

This Thesis is brought to you for free and open access. It has been accepted for inclusion in Dissertations and Theses by an authorized administrator of PDXScholar. Please contact us if we can make this document more accessible: pdxscholar@pdx.edu. 
A METHOdOLOGY FOR EVALUATING THE

EFFICACY OF TIIE PLACEMENT

PROCEDURES OF THE DALLES

COMIUNITY ATTENTION HOME

\author{
by \\ NARION ELLIOTT \\ PHIL EVASIENKO \\ NICHAEL HENDRICKS \\ ERMA MOOTRY \\ NANCY WEBSTER
}

A report submitted in partial fulfillment of the requirements for the degree of

MASTERS OF

SOCIAL WORK

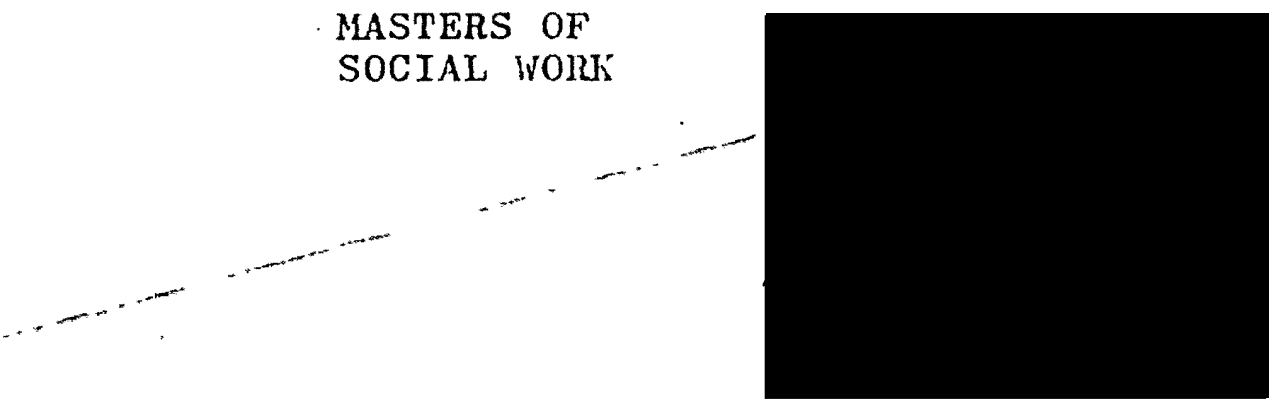

Portland State University

1975 


\section{ACKNOWLEDGEMENTS}

We greatly appreciate the help and cooperation of many interested people in the planning and implementation of this practicum.

We would especially like to thank: Mary Ellen Hammons, Social Worker, Mid-Columbia Center for Living; Von and Mary Wecker, houseparents of The Dalles Community Attention Home; members of the Probation Department in The Dalles; and Nancy Koroloff, faculty member of Portland State University School of Social Work. 
TABLE OF CONTENTS

PAGE

ACKNOILEDGEMENTS

SECTIONS

PROJECT DESCRIPTION 1

HISTORICAL BACKGROUND 2

THE COMMUNTTY ATTENTION HONE, THE DALLES, OREGON

Development

Current Administrative Structure 11

Present Operative Procedures 15

BACKGROUND INFORNATION AND ANALYSIS OF DATA 21

THE STATISTICAL DATA SHEET

THE TREATMENT ASSESSHENT SHEET

THE POST-PLACEMENT FOLLOWUP SHEET ' 29

RECOMMENDATIONS $\quad 33$

BIBLIOGRAPHY $34 \mathrm{~B}$

$\begin{array}{ll}\text { Appendix A } & \begin{array}{l}\text { Oregon State Standards for } \\ \text { Group Home Facilities }\end{array}\end{array}$

Appendix B Basic Information and House Rules 41

Appendix C Activity Consent Slip 43

Appendix D House Activity Schedule 44

Appendix E Medical Consent Slip 45

Appendix F The Statistical Data Sheet 46

Appendix $G$ Males residing at the Home longer than median compared to referral source 
PAGE

Appendix $H$ Males residing at the Home less than median compared to referral source

Appendix I Females residing at the Home longer than median compared to referral source

Appendix $J$ Females residing at the Home less than median compared to referral source

51

Appendix $\mathrm{K}$ Males residing at the Home longer than median compared to referral reason

Appendix $L$ slales residing at the Home less than median compared to referral reason

Appendix $M$ Females residing at the Home longer than median compared to referral reason

Appendix $\mathrm{N}$ Females residing at the Home less than median compared to referral reason

Appendix 0 Number of female referrals compared with age in years

Appendix $P$ Number of male referrals compared with age in years

Appendix Q The Statistical Data Sheet

Appendix R Monthly Statistical Data Summary

Appendix S The Treatment Assessment Sheet

Appendix $T$ The Post-Placement Followup Sheet 


\section{PROJECT DESCRIPTION}

The Community Attention Home, The Dalles, Oregon, provides services to those children, who, due to dependency, delinquent behavior, or family disruption, cannot remain within their present environment. The Home provides short-term shelter care with staff emphasis on proper diagnostic assessment for subsequent placement. Placement of children in the Home provides social service agencies time to plan for further care and/or treatment.

The project presents itself in essentially four major areas. They are: a descriptive presentation of data already available at the Home; a determination of what additional data need to be gathered for further evaluation of the Home's effectiveness; development of a system for collecting such data as are considered necessary for a further evaluation; and, a description of the statistical methods for the analysis of these data.

The information gathered and evaluated as a result of this study will be used by Attention Home staff for both program evaluation and development. This is the third in a series of studies which the Community Attention Home has sponsored for such evaluative and developmental purposes. 
"The historical and undifferentiated layers of the corrections stalagmite can be conventionally summarized as a succession of the three $R^{\prime} s$ : revenge, restraint and reformation." 1

A historical review of detention practices reveals the need for alternative facilities such as the Community Attention Home in The Dalles, Oregon.

Historically, the city of The Dalles has dealt with delinquent and dependent children by incarcerating them in the county jail, as they have had no juvenile detention facilities. The Comunity Attention Home was established to separate those children who are a danger to society or to themselves and need institutional care from those children who are dependent and are in need of shelter care. The city of The Dalles became aware of inadequacies in their existing mode of treating delinquent and dependent children. The Community Attention Home was established to enable the community to assess more adequately the needs of these semidelinquent and dependent children.

The criminal court system has existed for centuries. Prior to the 19th century, retaliation was the main tactic used to punish law violators. Accounts exist of people losing their ears after accusations of theft and individuals were often executed for minor offenses. During the late 19th

${ }^{1}$ Daniel Glasser, The Prospects for Corrections, paper prepared for the Arder House Conference on Manpower Needs in Corrections (1964), p. 1 . 
centary, the court system began to emphasize restraint. The court saw as its charge the duty to isolate delinquents from society. The philosophy of reforming social deviants did not take place and gain a firm hold until the 20th century. With the novement toward reform came the trend to provide separate facilities for juveniles. Illinois enacted the first juvenile court laws in $1899 .^{2}$ This reform instituted separate legal procedures for juveniles. The purpose was to provide the juvenile, because of his age, with special consideration under the law. Similarly, in 1907 Oregon passed a law requiring that juveniles be detained in separate facilities and not in jail. ${ }^{3}$ The court jurisdiction covered neglected children as well as dependent children. The court assumed responsibility for neglected children in order to protect them from their parents. The reform movement focused on understanding and changing the child so that he could return to his community environment. This concept conflicted with the traditional view which centered around punishment and restraint. The court, on one hand was attempting to view the child as sick, and on the other, to see him as needing punishment. The courts were thus trying to

${ }^{2}$ Lemar T. Empey, Contemporary Programs for Convicted Juvenile Offenders, Faces of Delinquency (1972), p. 360.

$3_{R}$. G. Vales, The Frazer Detention Home: Juvenile Court of Multnomah County, National Probation Association (1942), p. 7 . 
change the individual by both punishment and treatment.

The juvenile court was developed to save the juvenile from the "rigidity and severity" of the law." standards were not established in order that the court rould have the discretion in dealing with the child. Precisely how the court was to help a child was not clearly established. The court continued to use detention as a means of helping the child. For example, in 1942 detention was justified as a suitable place "to correct in children those delinquencies which could not be corrected by ordinary means", but standards for detention facilities were not uniformly estab1ished. 5 It was left with the court to decide what type of facility would best help the child. This resulted in a variety of detention facilities. The court system developed into a structure in which a child had no guarantee of individual rights inside or outside a detention facility. The product was:

"Existing correctional facilities are like stal-
agmite on the floor of a cave. Despite the fact
that new layers have been added to the basic pillar,
despite the fact that they add new dimensions to it,
they are not independent of the structure. The old
and the new are concealed into a sole, often un-
differentiated whole." 6

${ }^{4}$ Frederick B. Sussman, Law of Juvenile Delinquency,

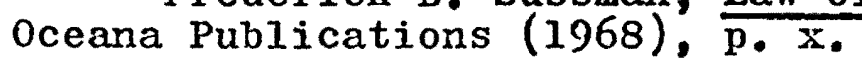

${ }^{5} \mathrm{R}$. G. Wales, The Frazer Detention Home: Juvenile Court of Nultnomah County, National Probation Association (1942), p. 8 .

${ }^{6}$ Lemar T. Empey, Contemporary Programs for Convicted Juvenile Offenders, Faces of Delinquency (1972), p. 362 . 
The current juvenile court administration contains several discrepancies. While the system itself connotes benevolence, it also continues to jail the child. Although the 1907 Oregon law suggested separate quarters, today all but five counties continue to detain children in county jails. 7 Even in Multnomah County, where there has been a separate facility, juveniles are now housed with adult women offenders and even when separate facilities have been provided, in appearance they still frequently look and operate like jails. According to the National Council on Crime and Delinquency, 100,000 children under the age of 18 were locked in jails during 1972. Ninety-three per cent of all United States counties have only jails or jail-like facilities for detaining juveniles. 8

Detention was initially proposed for children who were either dangerous to themselves or to the community. At present, the following definitions apply to children within the State of Oregon as coming under the juvenile court's jurisdiction: As per Oregon Revised Statute 419.476, the court has exclusive original jurisdiction in any case involving a person who is under 18 years of age and:

7J. H. Chapman, A Study of Juvenile Detention in Nultnomah County, Oregon, A Preliminary Report, (November 13,

${ }^{8}$ Norman Sherwood, National Council on Crime and Delinquency Annual Report, (1969), p. 6 . 
1. Tho has committed an act which is a violation, or which done by an adult would constitute a violation of a law or ordinance of the United States, or a state, county or city.

2. Who is beyond the control of his parents, guardian or other person having his custody:

3. Those behavior, condition or circumstances are such as to endanger his own welfare or the welfare of others.

4. Who is dependent for care and support on a public or private child-caring agency that needs the services of the court in planning for his best interests.

5. Either his parents or any other person having his custody have abandoned him, failed to provide him with the support or education required by law, subjected him to cruelty or depravity or failed to provide him with the care, guidance and protection necessary for his physical, mental or emotional well-being.

6. Who has run away from home. 9

Nevertheless, the criteria as to when detention should be used has never been clearly established and the use of detention is still frequently at the discretion of individual court workers, welfare workers, etc. As a result, counties vary in determining who will or who will not be detained. A recent report mentioned that within Multnomah County's juv-

${ }^{9}$ Oregon Revised Statutes 
enile court system there were many variances found in detention practices. The study reported that there were no clearly established procedures for determining who should be held. ${ }^{10}$ Among those held, nationally, the lower economic classes have been predominant. According to several recent studies, upper class children have committed the same number of crimes as those of lower class families. ${ }^{11}$ This suggests that class status and influence might be a determinant of whether or not a child is detained.

The disparity in detention practices results in a large number of children detained who are neither dangerous to themselves or to the community. The National Committee on Crime and Delinquency reported that less than 10 per cent of children apprehended warranted detention, but in practice 53 per cent apprehended nationally were detained. ${ }^{12}$ Besides being detained for status offenses such as runaway, juveniles are often detained in jails because there is simply no other place in which to put them. Oregon's law suggests that shelter care for certain children that don't require protection is available, but in actuality insufficient shelter

${ }^{10} \mathrm{~J}$. H. Chapman, A Study of Juvenile Detention in MultCounty, Oregon, A Preliminary Report, (November 13, 1975),

${ }^{11}$ Harwin L. Voss, Society, Delinquency and Delinquent Behavior (1969), p. 6i.

${ }^{12}$ Robert J. Gemingani, Diverting Youth from the Correctional System, HEl Publication No. 72-26009, (1972), p. 35. 
care facilities exist. 13 In questioning current detention practices, Dr. Bary, Oregon State Mental Health Division, stated that children with emotional problems, of which he estimates there are 55,000 in Oregon, need care badly. Many of them are in detention or juvenile homes instead of some place where they may be helped. 14 This suggests that even the sterile and jail-like atmosphere of a detention hall does little to promote emotional health. In summary, current policies militate to detain thousands of children in jail. These children have been held by vaguely defined criteria and for non-felony crimes. Probably the majority of the children detained do not require such secure custody, because a significant portion of such children are neglected but are not delinquent.

${ }^{13} \mathrm{~J}$. H. Chapman, A Study of Juvenile Detention in Multnomah County, Oregon, A Preliminary Heport, (November 13, 1973), p. 5.

${ }^{14} \mathrm{Dr}$ : Bary, editorial published in the Portland Oreconian, (November 12, 1972), p. 12 . 
THE COMAUNITY ATTENTION HOME, THE DALLES, OREGON

\section{DEVELOPRENT}

The Community Attention Home is located in The Dallos, Oregon, a city with a population of approximately 11,500 . The Home was established in 1971 to provide temporary shortterm shelter care and evaluative assessment prior to the placement of those adolescent children, who, due to dependency, neglect, delinquent behavior or family strife could no longer remain in their current living situation. The Community Attention Home serves the primarily agricultural areas of itasco, Hood River and Sherman counties in addition to the light industrial area of The Dalles.

Prior to the establishment of the Community Attention nome, approximately 95 per cent of the children who came in contact with authorities were placed in the wasco County Jail until alternative living arrangements could be planned and provided. The juvenile section of the Wasco County Jail is contiguous with both the women's and men's sections. Sensing the overall hostile environment and degradation of a jail setting in which further delinquent skills/attitudes night be learned, concerned citizens of the community began in 1970 to seek a reasonable alternative. These citizens formed the Juvenile Advisory Council, a committee to implement and plan a progressive program. The Council felt that if status offenders, court dependents and various other minor 
offenders were placed in a jail setting, feelings of rejection and hostility would only perpetuate and expand. The Council explored many alternative treatment modalities for children with delinquent behavior patterns and decided to place emphasis on a more caring, less punitive approach. The Juvenile Advisory Council felt it important that detention be used as a last resort and that it should be imposed only upon a limited population conforming to the below Iisted standards:

"No child should be placed in any detention facility unless he is a delinquent or alleged delinquent and there is a substantial probability that he will commit an offense dangerous to himself or the community or will run away pending court disposition. He should not be detained for punishment or for someone's convenience."I

The preliminary work of the Juvenile Advisory Council led to the founding of "Community Attention Home, Inc." in 1971, based largely on concepts that were first articulated in the initial Attention Home located in Boulder, Colorado. Contrasting the prevailing atmosphere of jail, the Conmunity Attention Home provides concerned houseparents, a home-like setting, assistance by the professional staff of various community social-service agencies and time for adequate planning and subsequent placement. Each agency concerned has the opportunity to work together to evaluate the child's needs while he is housed at the Community Attention Home.

${ }^{1}$ Information Digest, Criminal Justice Planning Resource Center of National Council on Crime and Delinquency (1969), p. 6. 
The Home atmosphere attempts to minimize mental and social adjustment problems of each child by keeping him within the community and in the company of his peers and by allowing him to continue, wherein possible or desirable, his regular activities such as school and employment. He is also encouraged to participate in community recreational and social activities. In short, the Community Attention Home works to provide a continuity rather than a disruption in the child's school and community life.

\section{CURRENT ADMINISTRATIVE STRUCTURE}

Community Attention Home, Inc., was formed as a nonprofit corporation initially funded on a $75 \%-25 \%$ matching basis with federal Law Enforcement Assistance Administration money. Local community projects/sales raised enough money to provide the down payment for the purchase of a house. Originally, Oregon State Children's Services Division paid $\$ 5.40$ per day per child in cost-of-care payments but the actual cost for Home care was estimated at approximately $\$ 15.00$ per day. The initial three year Law Enforcement Assistance Administration grant expires in 1975 and in the future, all funding will be provided through community resources. Children's Services Division will now pay \$14.50 per day for four children per day, whether four children are are actually there or not. If more than four children reside at the Home, a sliding scale will be applied. Ad- 
ditionally, the county will be billed at $\$ 14.50$ per day for those children placed through juvenile court. This is anticipated to barely meet the minimum $\$ 20,000$ per year budget the Home needs to maintain itself. Community projects and donated services will supplement existing funds.

A Board of Directors was elected from the membership of the corporation. The Board has responsibility for the administration and management of the Community Attention Home and its affairs. The Board of Directors presently consists of: Mr. Bob Ball (Chairman of the Board) - minister of The Dailes Presbyterian Church

Mr. Nick Hallett - principal of the Chenowith School

Ms. Pat May - housewife

Ms. Beth Reid - clerk, Wasco County Tax Office

Mr. Jim Roth - manager, Roth Music Store

Ms. Nicky Tom - housewife

Mir. Lee Wagner - schoolteacher, The Dalles High School

Ms. Rosemary Wolfe - supervisor, Children's Services Division

Mr. Gerald Grey - psychologist, Mental Health Center

The Board of Directors has described its organization, responsibility and purpose in the Board of Directors Publication as follows:

"Community Attention Home, Inc., is a non-profit, nongovernmental corporation located in The Dalles, Oregon. It is composed of interested citizens of the community who volunteer their services and support. Community participation and support at all levels of the program is encouraged and sought. The name 
of the corporation was chosen to demonstrate this founding principle: Active community involvement at the local level in recognizing, meeting and resolving the problems of the community, particularly those related to the youth, is an essential building block in a stable and human society that is responsive to the needs of it's individual members.

The responsibility of the program of Community, Attention Home, Inc., rests with the Board of Directors chosen from the membership at large. They have the authority to determine and direct the content of the program and to designate committees, individual members and employees of the corporation in carrying out those parts of the program they so designate. The Board is composed of nine members. A term of office is three years and one third of the Board membership changes each year, assuring continuity of the program as well as enabling the Board to be responsive to the membership and community.

Community Attention Home, Inc., was established after recognition of a very great need and scarcity of alternatives in the community other than jail for youth in disrupted family and/or home environments that precipitate a crisis and need for temporary care and shelter. This situation was considered intolerable. Community Attention Home, Inc., chose to reflect another basic principle in its name with emphasis on attention rather than detention as a method of dealing with many of the individual and social problems besetting our families and our youth. The word "attention" was borrowed from a program in Boulder, Colorado, and their work was used as a guide in establishing our own Attention Home proEram.

The house is equipped to handle both boys and girls in the general age range of 12-17 for a period not exceeding 30 days for a child. The capacity of the home is eight children at any one time. It is anticipated that the youth will fall into three general areas of classification or a component of the three basic areas: Children experiencing some family breakdown and/or unresolved parent-child conflict; neglected and dependent children; and those children involved in delinquent behavior."

Unique to the Community Attention Home as a whole is the desire to be entirely community-based and supported. During 
this year, the major source of support will be provided by local government in the form of cost-of-care payments with the second source coming from the community itself in the form of money donations, materials, fund-raising affairs and services. All furniture, appliances and house materials have been donated and ongoing maintenance is often supplied without cost.

Recently, the Board of Directors hired Mr. Edward Oppliger, a retired public school official, to serve as a business manager/administrator on a six-month contract. He is to be responsible to the Board and is acting in cooperation with the houseparents and other staff members. This position eliminates much of the administrative responsibilities for both Board members and the houseparents. It is not known at the time of this writing if this position will continue beyond the original six-month contract. The business manager's specific job description, as outlined in the Duties and Responsibilities of the Business Manager pamphlet is:

"The Administrator will supervise and direct the management of the Community Attention Home in areas of financing, budgeting, personnel, personnel recruitment, public relations, maintenance of property and record keeping necessary to the operation of these activities.

The Administrator will be directly responsible to the Board of Directors of Community Attention Home, Inc. The Board will provide him guidance and supervision.

The Administrator will work in cooperation with the houseparents, caseworkers and treatment committee in providing the best program available for the youth. He will ascertain if the policies regarding the Home are being implemented and carried out. 
The Administrator will be the liason of the Board with the houseparents, public and various agencies dealt with and is authorized to act on the Board's behalf.

The Administrator will report to the Board on a regular basis, such information that will keep them apprised of all aspects of the program. He will be available in providing guidance to the Board in any future development of service or program expansion."

\section{PRESENT OPERATIVE PROCEDURES}

The Community Attention Home meets the Oregon State standards for group home facilities. 2 It is located in a quiet, middle-class residential neighborhood close to schools, the city library, some recreational facilities, the city center and parks. The Home is relatively undistinguished from neighboring residential homes. The physical structure provides an adequate setting for the housing of both adolescent boys and girls. It is an older, large two-story structure consisting of five bedrooms, a living room, office, dining room, kitchen, three baths and a full basement. The basement area serves as a dormitory for the boys and also contains a workshop, laundry area and a bathroom. The upstairs is the housing area for the adolescent girls. There are two single rooms available and one large bedroom which two girls may share. Additionally, there is a kitchen area and sitting room for the girls upstalrs. The ground floor serves largely as a neutral meeting area where co-ed activities and general 
house business is conducted. There are books, couches, a color television, and a main kitchen area. The main floor also contains the houseparents' quarters.

The houseparents, Von and Nary Wecker, are a married couple with two small children. They were selected from a list of applicants by the Board of Directors. Their responsibilities at the Home is from Monday through Friday. Relief houseparents from the community take over on weekends. The houseparents continually upgrade their professional education by taking university courses at Portland State University on child development and management.

The houseparents are responsible for accepting or rejecting adolescent children into the Community Attention Eome. Those not accepted are children who are considered destructive, dangerous to themselves or others, or who are uncontrollable. The houseparents function largely as commonsense parents, providing both the discipline and structure required, plus recreational activities and guidance.

The Community Attention. Home and the houseparents begin with a process of helping the child with his imnediate situation. Formal therapy is not undertaken by the houseparents themselves, but they do try to initiate an informal pattern of helping relationships and in this way, provide an accepting and encouraging atmosphere.

The houseparents maintain a log at present on each child's behavior throughout the week that has been exten- 
sively used at the weekly staffings. The houseparents' input at these staffings is considered essential to proper evaluation and placement. The houseparents are additionally responsible for adequate dietary planning, for buying supplies, for providing transportation as needed and for ensuring the general upkeep of the Community Attention Home. Children are referred via the Juvenile Department, Children's Services Division and Juvenile Parole. These are the agencies who have responsibility for paying the cost-ofcare payments for the children who are placed in the Home. Providing evaluation, assessment and casework plans, counseling and the implementing of a treatment design are the joint responsibility of the half-time psychiatric social worker employed by Community Attention Irome, Inc., the Juvenile Department, Claildren's Services Division, the Mid-Columbia Center for Living and the houseparents.

It is estimated that approximately $35 \%-40 \%$ of the children are referred for shelter care only and that approximately $50 \%$ are referred on an evaluative and placement basis. The remaining $10 \%-15 \%$ represent a combination of both the above categories. Children who are in school at time of referral or desire to attend school are encouraged to do so. others, providing they have jobs, may work. Those children who neither work or attend school remain within the confines of the Home during the day, doing assigned chores or engaging in recreation. They must conform to the same schedules, rules 
and requirements as do all other children in the Home.

The houseparents are responsible for regulating the children's behavior within the Community Attention Home: enforcing rules, delegating duties, encouraging school attendance, and in general, acting in the child's interest. Mome information and basic rules by which the children are expected to abide are given to each individual upon entrance. 3 The houseparents believe that certain daily maintenance and work experiences are useful for adolescents. They believe that it is important therefore that the boys and girls have responsibility for taking care of their orm living areas and other chores.

The houseparents use no merit or point system or any other behavior-enforcing modality other than the restricting of privileges. These largely include free time and visiting rights. Such restrictions have been very effective in molding behavior to meet the expected norms. In a few drastic cases where such restrictions have been ineffective, the alternative has been placement in the Wasco County Jail.

The houseparents are also responsible for implementing and coordinating a recreational program. 4 They also ensure adherence to an activity, curfew and feeding schedule. 5

${ }^{3}$ See Appendix $B$.
${ }^{4}$ See Appendix $C$.
${ }^{5}$ See Appendix $D$. 
It is the houseparent's duty to provide all the minimum physical and personal effects needs of children, such as clothes, toothbrushes, etc. They also ensure that needed medical attention is provided when necessary. When possible, they turn to the original family physician via a signed consent form. ${ }^{6}$ There is a required physical examination before entrance into the Community Attention Home. The Home receives regular inspections by the fire marshal and the health department, and the houseparents are responsible to see that the Home meets those standards set forth.

Important to the operation of the Community Attention Home is the cooperation among concerned social-service agencies (specifically, the Fid-Columia Center for Living, Juvenile Court and Children's. Services Division) in accomplishing diagnostic assessment, evaluation, planning and subsequent placement in the case of each individual child. Staffings are held in the Home on Mondays with representatives from the above agencies in attendance, plus the houseparents. They are conducted on an informal basis. This mutual effort culminates in a cooperative decision about-what is considered in the best interests of each child. If it is felt that anything further is needed before such a decision can be reached, such as individual therapy or psychological testing, arrangements are nade at the staffings to have these implemented.

${ }^{6}$ See Appendix E. 
Coordination of the staffings, though not formally specified, is normally conducted by Ms. Mary Ellen Hammons, M.S.W., of the Mid-Columbia Center for Living. Ms. Hammons is the halftime psychiatric social worker employed by Community Attention Home, Inc. As such she plays a key role in the running of the Home and is involved in each child's individual treatment plan. She also serves as a valuable treatment resource for the houseparents. 


\section{BACIKGROUND INFORNATION AND ANAYLSIS OF DATA}

The Community Attention Home in The Dalles provided their records on placements entering that facility between the months of December 1972 and December 1973. The following is a descriptive presentation of data previously gathered by Attention Home staff via their original intake form. 1 From derived data, a number of observations can be made. Appendixes $G$ through $P$ graphically depict the following information.

During this period, admissions to the Community Attention Home totalled 83, of which 55 were males and 33 were females. Ten of the 55 males who resided in the Howe between December 1972 and December 1973 repeated their stays two or more times and thus accounted for 25 of the total number of male admissions. Two females who repeated their stays accounted for six of the 33 female admissions.

Ages ranged, for the males, from 12 to 17 years, with a mean* age of 14.6 years and a median age of 14 years. Females ages ranged from 12 to 19 years, with a mean age of 15.5 years and a median age of 16 years. Twenty-three of the males $(42 \%)$ and six of the females (19\%) had been residents

*The mean is obtained by adding together a group of numbers and dividing by the number of cases in the group. The median is obtained by arraying a group of numbers from the lowest to the highest and then finding that number at which $50 \%$ of the group is lower and 50\% is higher.

${ }^{1}$ See Appendix F. 
of the Community Attention Home prior to the period between December 1972 and December 1973.

Almost one-half of the male and considerably fewer of the fenale referrals entering the Home had juvenile court records prior to the current referrals. Twenty-three of the 55 males $(42 \%)$ and six out of the 33 females (19\%) possessed prior records.

The mean number of days detained at the Community Attention Home for the males was 15 days; the median was nine days. Females were detained a mean number of 16.6 days and a median of 11.5 days. For the males and females combined, days detained ranged from a minimum of one day to a maximum, in one instance, of 61 days.

A majority of the referrals for the males, 33 out of 55 $(60 \%)$, were made by the juvenile court, while 13 other referrals $(24 \%)$ were made by Children's Services Division. The remaining nine referrals were divided among The Dalles Police Department, parents and self-referrals. Similarly, for the females, of the total of 33 referrals, 16 (49\%) were made to the Home by juvenile court, while 14 referrals ( $43 \%$ ) were made by Children's Services Division, one by The Dalles Police Department, and two were listed as unknown.

Among the males, reasons for referral varied with the most frequently appearing reason being "beyond parental control" (29\%) and "runaway" (22\%). Females were also wost frequently referred for both "beyond parental control" (46\%) 
and "runaway" (35\%), plus for failure on the part of the parents to "provide care, guidance and protection" (18\%). Recurring entries account for some duplication of data if the total population of individuals is the object of consideration. In these cases, data regarding age, prior record, intactness of family, prior residency in the Home, ethnic group and school and employment status are most affected. However, the data do accurately and realistically reflect the characteristics of the population which the Hoine encountered at any one time and over the entire period. liepeaters affect the frequency with which their particular traits or problems occur and must be dealt with.

It is interesting to note that in the section of the intake form entitled "Intake Goal Net", all but six of the total of 31 repeating entries report success in meeting the designated intake goal at the time of the first referral. Why these children continued to return to the Howe, however, is not evidenced on these intake forms.

A number of observations became evident in looking at the intake forms by entry. Some relate to the ambiguities in the form itself and are worth noting. Several of the entries call for a judgement on the part of the person filling out the form or depend on some unspoken consensus about the meaning of that particular entry. For example, in the section marked "Euployed", there is no specification as to what constitutes "employed". Questions arise: Does "employed" mean 
vorleine full or part-time? Riust a child be employed while in the Ilome to receive a "yes" on the form? lust he merely have been employed at the time of his encounter with the authorities? Similar questions arise about being "In School". Does this mean that the child is in school while in the Home, enrolled but not necessarily attending, or in school directly prior to the referral? Probably those using the form had answered these types of questions in their ow minds before recording each time, but the consistency of their responses comes into question. With this, comes into question much of the reliability of the data derived from this form. We suggest that the above issues be addressed by all persons using the Statistical Data Sheet in order that consistency can be waintained in their record lreeping.

Additional kinds of information need to be obtained and the following sections present a description of such data. 


\section{THE STATISTICAL DATA SHEET}

Pursuant to the Community Attention Home staff's request for the development of a data-gathering system, the Statistical Data Sheet was developed from the data sheet used in the Community Attention Iome between December 1972 and December $1973 .^{I}$ It includes essentially the same items as were on the original sheet, with two principal exceptions. One is a reduction in the numiser of items listed in the "referral Source" category. Analysis of the original data sheet revealed that two sources provided the substantial majority of referrals to the Ilome. These two are the orezon State Children's Services Division and The Dalles Juvenile Court. As a result, the "Referral Source" section has been reduced to include only those two items plus "Other" and a space to identify the source (if it is neither the Juvenile Court or Children's Services Division).

The other principal change involves a reduction in the number of items in the "Placement" section. Agrain, analysis of the original sheet revealed that only a few of the items included there vere used with any frequency. As a result, the number of items in this section has been reduced from twenty-three to three itens pIus "Other" and a space to identi̊ly.

Two categories have been added. One refers to intake

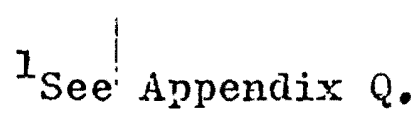


goals, and asks for a specification as to whether the child is in the Home for "Shelter Care" or for "Evaluation for Placement". Also added is a section which asks for a brief narrative describing the circumstances leading to the child's referral to the Home.

Finally, it will be noted that all items on the data sheet are numerically coded. Such coding will provide a statistical basis for future analysis of the data gathered.

Data from this form can be collected on a monthly basis via a sumary sheet. ${ }^{2}$ Here information from the individual sheets will be totalled for the month, and from these totals, frequency data (percentages) of each item may be derived. For example, in the section referring to the sex of the referral, the percentage of nale referrals to female referrals may be quickly determined and compared, when such information is desired.

The Statistical Data Sheet was first submitted to the staff of the Community Attention Howe in December 1974. It was subsequently revised according to staff suggestions and has been in use in the Home since January 1975. 


\section{THE TREATMIENT ASSESSMENT SHEET}

In addition to the revised Statistical Data Sheet, we are suggesting the utilization of a Treatment Assessment Sheet. $^{1}$ on this form, the Home worker can record not only essential admission information but also the behavioral descriptions of the child's activities and attitudes while within the Home. This takes the place of the log maintained at present in which occasional information is written on an irregular basis and also the new form readily provides for formal evaluation in the future. Admission information is divided into a general section, a section referring to the child's health, a section requiring a description of his attitude regarding admission and a section referring to his personal effects upon admission.

The behavioral section of the Treatment Assessment Sheet provides for entries regarding the child's school and job performance, his compliance with Attention Home regulations, contacts with relatives, contacts with houseparents, formal psycho-social evaluations, family and individual sessions, and the child's interactions with peers within the Home. Currently, there is no central case record for each referral. We believe that this Treatment Assessment sheet can providè a base structure for organizing all pertinent data on each child. It should be completed weekly. Decisions 
need to be made within the Home regarding responsibility for who keeps these records and how and where they are filed. The Treatment Assessment Sheet was submitted to the staff of the Community Attention Home in December 1974 with the Statistical Data Sheet. It was revised according to staff suggestions and has been in use at the Home since January 1975. 


\section{THE POST-PLACENENT FOLLOWUP SHEET}

The Post-Placement Followup Sheet is a questionnairetype instrument designed to evaluate the Community Attention Home's program objectives and goals. ' This evaluation is accomplished by comparing questionnaire results with a standard level of performance for each objective. A description of the statistical methods for analyzing these data follows.

The Dalles Community Attention Home states as its primary goal the effective placement of children in subsequent care facilities. This also includes children returned to their orm home. At the present time, no criteria have been established for measuring the effectiveness of such placements. The effectiveness of each placement may be measured in terms of objectives which in this case refers to the child's behavior while he resides in the placement. The questionnaire, with a cover letter to the specific placement, has been designed to collect information concerning a child's general behavior.

In order to evaluate the goals and objectives, questionnaire results are compared with a standard level of performance. Since an appropriate control is not available nor has there been an established level of performance, we suggest that an arbitrary level of standard performance be estab- 
lished. The validity for establishing an arbitrary standard has been explained. ${ }^{2}$ This standard should reflect what the Commity Attention Home staff believes to be a successful performance level.

This criterion should also reflect the level, which, if not met, indicates that the staff needs to re-evaluate its program. We suggest that the Home staff select an effectiveness criterion to be measured by the questionnaire. The use of that success level is described here: Defining the representative group. A record is lept listing each child's name and the residence in which he was placed inmediately following his stay at the Community Attention Home. The followup questionnaire is sent to this residence/placement three months after the child leaves the Home. The placement then reports the child's overall behavior by responding to the questionnaire's statements. All forms returned are analyzed. The Home would also have the option of analyzing the forms on six and twelve month intervals. A sampling technique could also be used. For example, every third response received could be pulled and this group analyzed. The questionnaire can also be separated into categories based on the type of placement. For exarple, children placed in their orn homes, group homes,

${ }^{2}$ Clarkson, Quentin D., Neuburger, Wayne F., Koroloff, Nancy M., Some Statistical Aspects of Program Evaluation, 
foster care or institutions may be reviewed separately. Such a separation would allow for a comparison of success rates in differing placements.

Scoring the questionnaire. Each question is weighed as success or non-success according to the response. For example, if the answer to "Does this child have conflicts with adults?" is "yes", then this response is considered not successful. Successful responses are given a score of one and non-success a score of zero. If the experience shows the items are additive, each score can be added. Also the questions may be grouped as to behaviors and the points for each behavior scored. For example, the number of success scores for "Does this child have conflicts with adults?" is added then analyzed.

Determining appropriate statistics. The total scores of each question or behavior provides the number of successful responses. This number is compared with the number of success responses possible for that specific question or behavior. By computing a percentage, comparing the question's actual score with the total possible points, a percent score can be obtained. For example, if a question scores 8 out of 10 possible successful responses, it has an $80 \%$ success score. A percent score is computed for each question. These frequencies can provide a series of scores that may then be compared to fully evaluate the program.

Comparison analysis. The above percentages are used 
to obtain a descriptive summary of the questionnaire's results. The percentages are also compared with an arbitiary standard level of performance. If the score equals or exceeds such a standard, then it is considered to be a successful placement with regard to that specific behavior. Thus each behavior can be measured as success or non-success. Then the percent of successful behaviors can be compared vith the total standards criterion. For example, if $80 \%$ of all behaviors are successful and $80 \%$ is the established criterion, then the Community Attention Home's program is considered to be meeting its goals of placement. Should the percentage fall below the standard, a re-evaluation may be in order. Such analysis can indicate possible directions for decisions concerning the overall program. 


\section{RECORMENDATIONS}

The recommendations noted here reflect the concerns voiced by each of the agencies which have input into the functioning of the Community Attention Home.

Foremost among the needs expressed by these agencies is the establishment of a central record-keeping system. We believe that the forms we have devised will contribute to the implementation of such a system.

Attending this need for a central records file, we note a need to define exactly which agency has case responsibility for each child. At present, this is done at staffings by means of an informal agreement. We recormend that agreements be formalized in a document which indicates exactly who has case responsibility for each child at all times. This would benerit all agencies involved as they attempt to coordinate a comprehensive plan for each child or for his entire family. We suggest that a written tracking system be lrept in a central nermanent location where all information regarding case disposition can be made available to all arencies requesting information.

Hembers of arencies using the Conmunity Attention Howe facilities have expressed a desire for an established criterion describing the basis on which children are accepted into the Iome. Currently, the houseparents have total authority to offer or deny aduittance to all children recomnend- 
ed for placement by any of the local agencies. It is apparent that established criteria for admittance would work to prevent possible inequities in the admittance process. The houseparents and the members of the juvenile court have expressed concern about the need for substantial and constructive activity for those adolescents who neither work or attend school. We believe that a general notification to the community might generate activities in terms of part-time ox volunteer jobs for these children.

In view of the current minimal financial situation, we suggest that the business manager conduct a cost-effectiveness or cost-jenefit analysis for each child and for the entire Howe. Along with the dollar infornation, measures of program effectiveness in non-dollar terms should be developed. Such measures might describe the Home's functioning with regard to such things as recidivism rates, cohesiveness of families whose children have had Home care, rates of maintaining children in school, etc.

Finally, with regard to the Statistical Data Sheet and Treatment Assessment Sheet, we recommend that the Home staff establish uniforn definitions for entries. This would improve reliability of statistics and their interpretation. 
Bibliography

Buxbaum, Edith, Troubled Children in a Troubled World, International Universities Press, Inc., New York, 1970.

Chapman, J. H., A Study of Juvenile Detention in Multnomah County, oregon - A Preliminary Report, c. 1973.

Clarkson, Quentin A., Neuberger, Wayne F., Koroloff, Nancy, Some Statistical Aspects of Program Evaluation, Portland State University, Oregon, 1975.

Clitheroe, David; Long, Garrett, $\Lambda$ Attitudinal Study of Selected Groups in the City of the Dalles toward the Community Attention llome, Portland State University, Oregon, 1972 .

Conger, John J., Adolescence and Youth: Psychological Development in a Changing World, llarper \& llow, New York, 1973.

Dornbusch, Sanford M., and Schmid, Calvin F., A Primer of Social Statistics, McGraw-Mill Book Company, New York, 1955.

Empey, Lemar T., "Contemporary Programs for Convicted Juvenile Offenders", Faces of Delinquency, Prentice Hall, Inc., New Jersey, 1972.

Gemingani, Robert J., "Diverting Youth from the Correctional System", Dept. of Health, Education and Welfare Publication No. 72-26009, 1972 .

Gilstrap, Landon; Larson, Joyce, and Page, Janice, A Followun Attitudinal Study of Selected Groups in the city of The Dalles toward The Community Attention Ilome, Portland State University, Oreoron, 1973.

Glasser, Daniel, "The Prospects for Corrections", paper for the Arder House Conference on Manpower Needs in Corrections, mimeographed, 1964 .

- Information Digest, Criminal Justice Planning Resource Center, National Commission on Crime and Delinquency, New York, 1969.

Kahn, Alfred J., Planning Community Services for Children in Trouble, New York, Columbia University Press, 1963. 
340

Sherwood, Norman, National Council on Crime and Delinquency rCD Amanda Report, Washington D.C., 1969.

Sironson, Charles T., "Annual Meeting of National Juvenile Detention Administrators' $\Lambda$ ssociation", Humanizing the Juvenile Detention Process, Chicago, Illinois, c. 1970.

Sussiann, Frederick B., Law of Juvenile Delinquency, Ocean Publications, Nev York, !es York, 1968.

Doss, IIarwin L., Society, Delinquency and Delinquent Behavior, Little and Brow, Boston, massachusetts, 1969.

Vales, R.G., "The Frazer Detention Horse: Juvenile Court of Inutnomah County", National Probation $\Lambda$ ssociation, New York, Te: York, $19 x_{2}$. 
APPENDIX A

OREGON STATE STANDARDS FOR GROUP HOME FACILITIES

Group Home requirements within the State of Oregon are as follows:

0.R.S. 22.120.2 Group Shelter Home. A home with no more than nine children residing therein, including the children related to the group home parents; provided that there shall be no more than two children under the age of three residing therein at any time, and provided further that no foster child resides therein more than 60 continuous days.

0.R.S. 22.140 Requirements of the Group Home. In order to qualify for or to maintain a certificate the group home shall:

(1) Be located in a neighborhood which is accessible to school, church and medical facilities;

(2) Comply with applicable state and local fire, sanitary, and safety conditions and regulations;

(3) Provide adequate screening for fireplaces and openfaced heaters;

(4) Adequately protect the foster child from guns, drugs, poisons, disinfectants and any other materials which are inherently dangerous to children;

(5) Maintain adequate standards of cleanliness;

(6) Be served by a public water system and a public sewage system - unless a written statement signed by a health 
officer or a sanitarian which approves the sanitary conditions existing in the group home is secured and filed with the Branch office;

(7) Furnish adequate sleeping facilities which:

(a) Provide the child with a finished, well-ventilated, heated, and well-lighted bedroom which has an outside window and is within call of a responsible adult;

(b) Are not located in a building which is detached from the main house;

(c) Provide sufficient bedroom space to assure that unrelated children of the opposite sex who are over the age of two years shall not occupy the same bedroom;

(d) Provide each child with an individual, comfortable and adequate bed provided that two brothers or two sisters may share one double bed, preferably for a temporary period only;

(e) Provide sufficient bedroom space to assure that related children of the opposite sexes over the age of six years do not occupy the same bedroom;

(f) Insure that no more than three children of any age shall occupy the same room;

(g) Insure that no child over one year of age shall sleep in the same room with an adult of the opposite sex except in a case where the child's illness requires special care.

(8) Provide each child with individual drawer space for possessions and with suficient closet space for clothing; and 
(9) Provide adequate space for indoor and outdoor play.

0.R.S. 22.145 Requirements of the Group Home Family. In order to qualify for or to maintain a certificate, a group home family shall:

(1) Include the applicant and his spouse unless special approval is granted by Children's Services Division;

(2) Not have a group home mother employed outside the group home unless said employment is not detrimental to the best interests of the children based on a review of all the surrounding circumstances including but not limited to the age of the children, the hours and nature of the employment and the needs of the children;

(3) Provide supervision by a responsible person at all times;

(4) Prevent the presence in the household of any individual who would be harmful to the welfare of the children;

(5) Possess character, habits and personal relationships which are harmonious and wholesome in order to give the children the understanding, affection and security needed to develop into a responsible adult;

(6) Not require a child to do work which jeopardizes their health or interferes with either their schooling or normal recreation;

(7) Not administer severe or harsh punishment to a child;

(8). Provide opportunities for the foster child to attend religious services in accordance with their religious affilla- 
tions or in accordance with the wishes of their parents or parents;

(9) Have a sufficient income to meet its needs without the board payments made on behalf of the child;

(10) Not combine full-time foster care with boarding, nursing or convalescent care for adults;

(11) Not combine foster care with day care for children if in the judgement of Children's Services Division such day care is harmful to the welfare of the children;

(12) Provide the children a well-balanced and nutritious diet of sufficient quantity;

(13) Provide only pasteurized milk to a child, except that milk secured from a licensed producer-distributor of raw milk may be used as well as other raw milk which is pasteurized in accordance with the methods approved by the Department of Agriculture;

(14) Not accept for care, a child who has any evidence of a communicable disease, or accept for care any child when there is evidence of a communicable disease within the home, and

(15) Comply with all applicable state and federal laws and rules.

0.R.S. 22.150 Additional Reguirements for Certain Group Families. If the child has been placed with the family by the Branch office, the family shall comply with the following additional requirements:

(1) Immediately report to the Branch office any unusual 
change in the circumstances of the child including but not limited to illness, injury, disappearance, planned absence, behavior problems at home, school or in the community, lengthy absences from school or change of address;

(2) Not remove the child from the state without permission of the Branch Office;

(3) Maintain a record of each child received into care and keep said records in a register provlded by the Branch office which can be made available upon the request of the Branch office.

0.R.S. 22.190 Recertification. Application for recertification of a group home shall be made in the same manner and subject to the same conditions and requirements as upon the original application, except that the application for recertification shall be made at least 15 days but not more than 90 days immediately preceding the date of expiration of the existing certificate.

0.R.S. 22.200 Revocation. Children's Services Division shall revoke any certificate that the group home or group home parents have upon determination that they are not in compliance with state or federal laws or applicable rules or, if in its judgement, the physical and emotional needs of the child are not being met.

(1) Children's Services Division shall notify the group home parents by mail at their last known address of its decision to revoke;

(2) The Branch office may cause a child who is in custody 
of Children's Services Division to be removed from a group home pursuant to an order of revocation without subjecting itself to civil liability for effecting such removal. 
APPENDIX B

\section{BASIC INFORMATION AND HOUSE RULES}

The Attention Home in Wasco County has been formed by this community and it is a privilege to stay here. Our home is here for you. We believe in you as an individual and hope you can learn to live within the rules here.

As in each group living situation, each person in the house will share in the responsibility and upkeep of the home. For everyone's mutual conventence there will be a scheduled time to have meals.

You will be provided with a special place to keep your personal things. Many personal items can be provided by the houseparents. You may not borrow any items from other occupants unless prior approval is granted by the houseparents.

In the interest of the other people in the home, everyone is required to bathe at least once every two days.

Some privileges are lost to you while living in the home. You will not be allowed to bring or to use the following items of personal property: 1. Motor vehicles 2. Pets.

The houseparents, in agreement with the Juvenile Department, will establish permission to leave the home based on individual situations of each resident.

No outgoing telephone calls will be allowed unless given special permission by the houseparents.

A certain area of the house will be designated as a smoking area by the houseparents. Bedrooms, upstairs areas and basement areas cannot be used because of fire danger.

No alcohol or drugs are allowed in the Attention Home. Residents will also be held responsible for any violations of this rule that their friends or guests make while visiting the home.

Certain areas of the home are to be designated for entertaining friends and relatives. There will be certain hours set aside for visits. On some occasions, visits must be approved by the Juvenile Department. 
Welcome to our home. This is a special home where you have a chance to work through some of the problems you are experiencing. We cannot change situations such as broken homes or personalities of parents and others you live with. But we can help you in looking at your part in the problems and how you can better cope with them. This is our purpose. We hope you can take advantage of what our home has to offer. 


\section{APPENDIX C}

\section{AGTIVITY CONSENT SLIP}

has ry consent to engage in the following activities while residing at the Community Attention Home. All activities will be supervised.

Swimming (pool)
Swimming (river)
Water Skiing
Horseback riding
Hiking
Basketball
Volleyball
Trampoline
Boat Riding
Roller Skating
Other

Date : 
APPENDIX D

\title{
COMRUNITY ATTENTION HOME
}

- House Activity Schedule -

\begin{abstract}
Monday - Day out on own after school (known destination); visiting if desired until 10:00 p.m.

Tuesday - House activity out; no visiting.

Wednesday - Day at home; visiting if desired until 10:00 p.m.

Thursday - Day at home; no visiting (concentrate on homework).

Friday - Day out on orn after school (known destination); visiting if desired until 12:00 midnight.

Saturday - House activity out. Visiting 10:00 a.m. until 2:00 p.m., 6:00 p.m. to 8:00 p.m. (hours flexible depending on when the activity takes place).

Sunday - Day at home; visiting 12:00 noon until 10:00 p.m. if desired.

- - - - - - - - - - - - - - - - - - - - - - -

Weekdays - Breakfast (7:30) Lunch (12:30) Dinner (6:00)

Weekends - Breakfast (10:00) Lunch (2:00) Dinner (6:30)

- Curfew hours -

Weekdays $-\left\{\begin{array}{l}\text { ages } 15,16,17 \\ \text { ages } 12,13,14\end{array}\right\} \begin{aligned} & \text { must be in by 10:00 p.m. } \\ & \text { must be in by 9:00 p.m. }\end{aligned}$

Weekends - (ages 15, 16, 17) must be in by 12:00 midnight.

Everyone to respective quarters by 10:30 on weekdays and by $12: 30$ on weekends.
\end{abstract}


APPENDIX E

MEDICAI CONSENT SLIP

Date:

If, while in the care of the Attention Home, should develop a condition which requires hospital treatment, I hereby consent to such treatment, and, if the administration of an anesthetuc or the performing of an operation is advisable, this has my approval.

I further authorize such steps as may be deemed necessary to render this child immune to smallpox, diptheria and other communicable and contagious diseases.

Name

Address

Relationship to child

Witness 


\section{APPENDIX $\mathrm{F}$}


STATISTICAL DATA SHEET

CASE NO.

SEX: $\quad \mathbf{M} \quad \mathbf{F}$

ETHNIC GROUP:

1. White

2. Black

3. Am. Indian

4. Mexican

5. Oriental

6. Other

AGE :

DATE OF BIRTH:

REFERRAL SOURCE:

01 Dalles Police

02 Wasco County Sheriff

03 other Police or Sheriff

04 School

05 Social Agency

06 Juvenile Court Counselor

07 Parent or relative

08 other court

09 Self

10 other

REASON REFERRED:

01 Motor Vehicle Theft

02 Possession Stolen Vehicle

14 Harrassment

15 Truancy

03 Unauthorized Use Vehicle

16 Runaway

04 Burglary

05 Criminal Trespass

06 Loitering

07 Robbery

08 Shoplift

09 Criminal Mischief

17 Beyond Parental Control

18 MIP Alcohol

19 Curfew

20 Use of Drugs

10 Forgery

21 Abandoned

11 Arson

12 Disorderly Conduct

22 Failure to Provide Care, Guidance and Protection

23 Cruelty by Parents

13 Resisting Arrest

24 Other

PLACEMENT PRIOR TO HOME:

DETENTION USED DURING REFERRAL PROCESS: YES No PRIOR COURT RECORD: YES NO

FAMILY INTACT: YES

NO

IN SCHOOL: YES __ NO

EAIPLOYED: YES NO

INTAKE SERVICE GOAL:

INTAKE SERVICE GOAL MET:

Satisfactory

Partially met

Unsatisfactory 
PRIOR RESIDENT OF HOME: YES — NO

LENGTH OF STAY: Date Received

Date Discharged

PLACEMENT AFTER HONE:

01 Orm home or no change

02 Children's Services Division

13 Christie

03 Relative

04 Acheson House

05 Boys \& Girls Aid

14 Dammasch

15 Edgefield

16 Fairview

06 Carroll House

17 Hillcrest

07 The Inn

08 Seghers House

09 Yaun Home

10 Youth Adventures B/G

11 Youth for Christ

12 Children's Farm Home

18 Louise

19 MacLaren

20 Parry Center

21 St. Mary's

22 Villa St. Rose

23 Waverly

24 other 
APPENDIX G

MALES RESIDING AT THE COMRINITY ATTENTION HOME FOR GREATER THAN THE NEDIAN (9) NUMBER OF DAYS COMPARED TO THEIR REFERPAL SOURCE
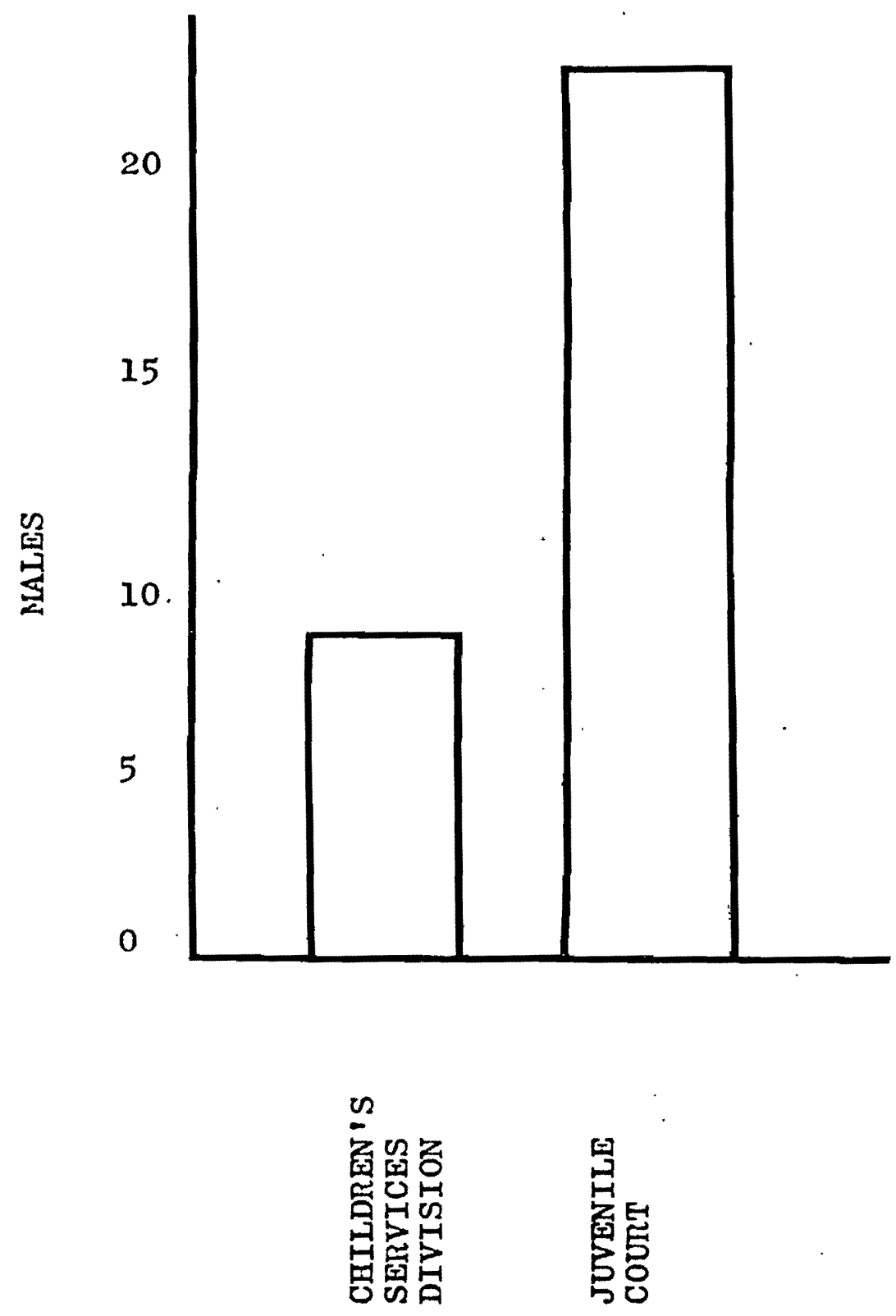

REFERRAL SOURCE 
MALES RESIDING AT THE CONMUNITY ATTENTION HOME FEWER THAN THE MEDIAN (9) NUMBER OF DAYS COMPARED WITH THEIR REFERRAL SOURCES

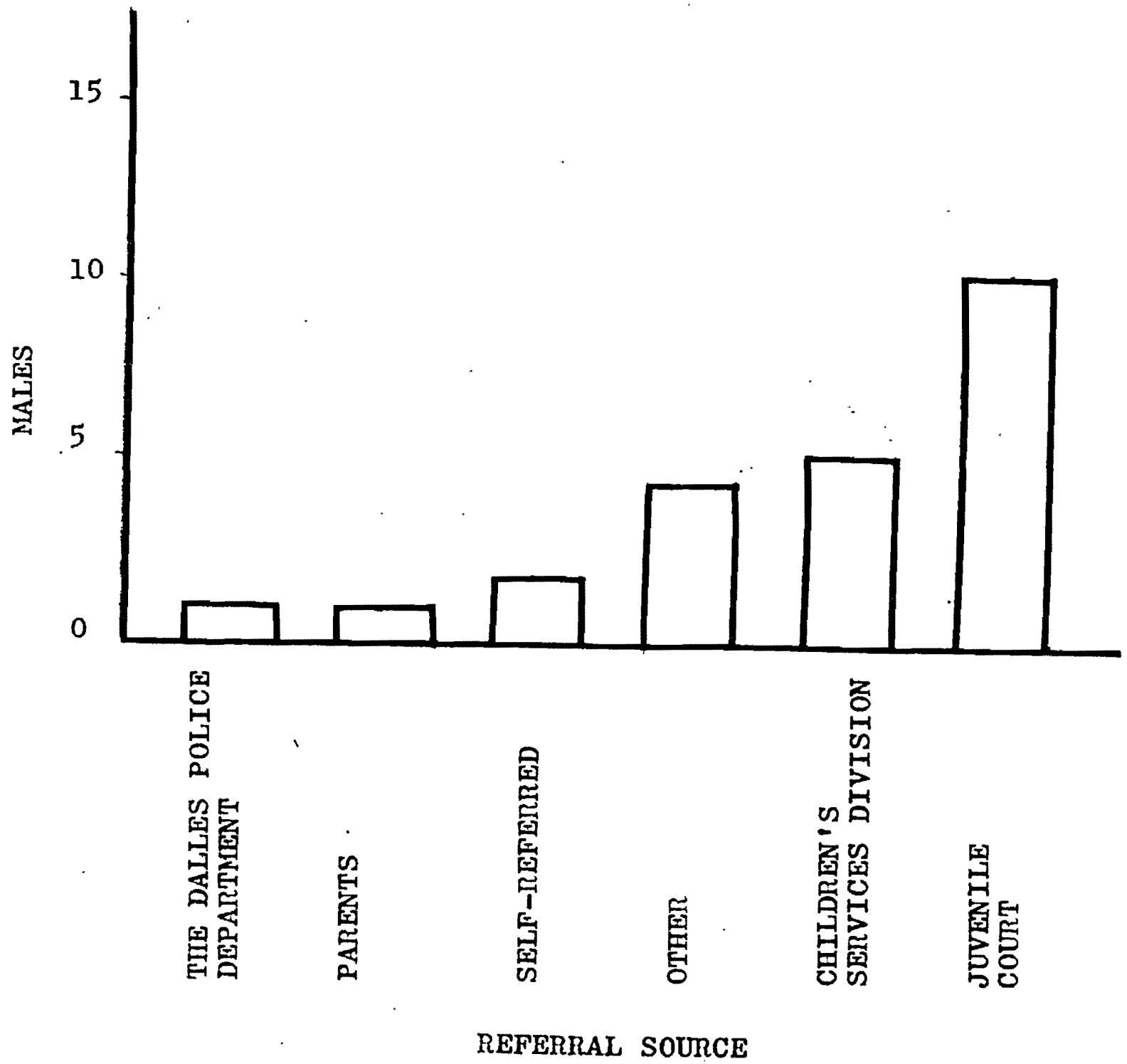


FEMALES RESIDING IN THE CONRINITY ATTENTION HONE GREATER THAN THE MEDIAN (11.5) NUABER OF DAYS CONPARED TO THEIR REFERRAL SOURCES

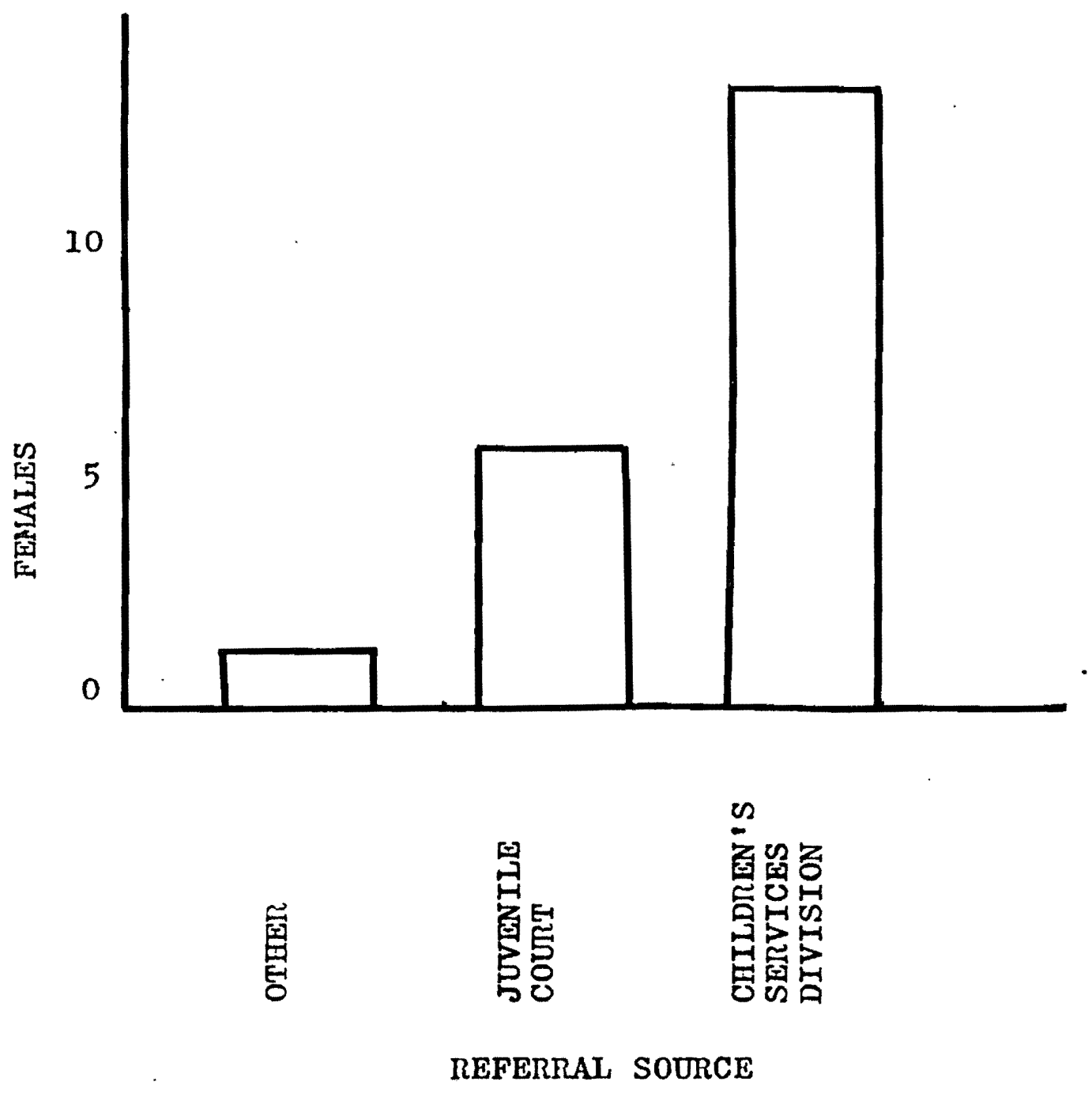


APPENDIX $J$

FERLALES RESIDING AT THE CONRINITY ATTENTION HOME FETVER THAN THE MLEDIAN (11.5) NUMER OF DAYS COMTARED WITH THEIR REFERRAL SOURCES

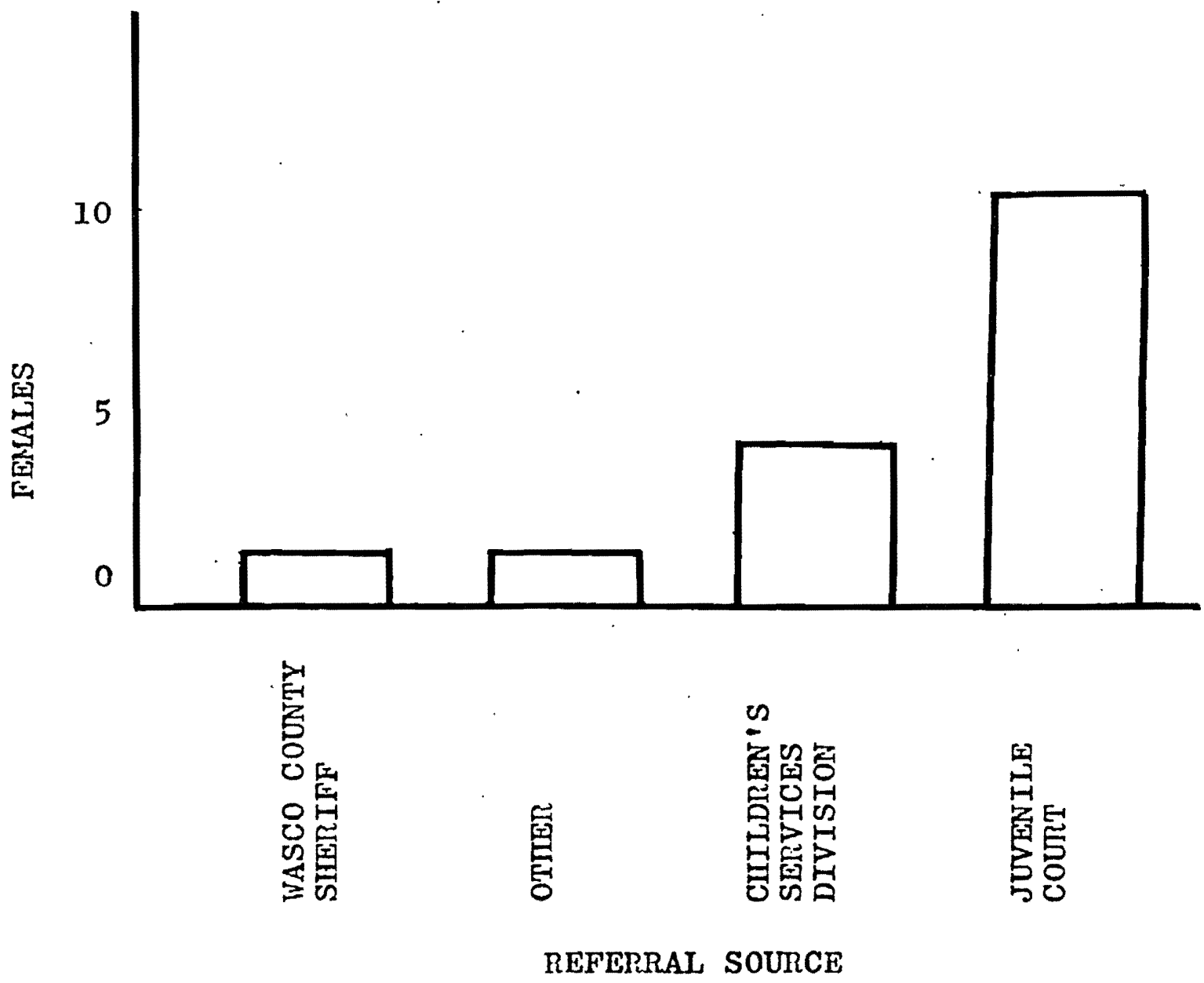


APPENDIX $K$

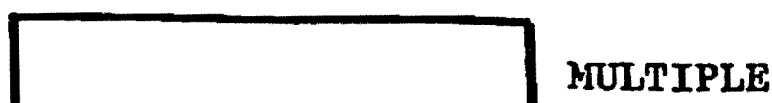

PLALES DETAINED AT THE CONAIUNITY ATTENTION IIOIE G?EATEP THAN THE NEDIAN (9) NURIBER OF DAYS CONIPARED TO THE REASONS FOR REFEIRAL

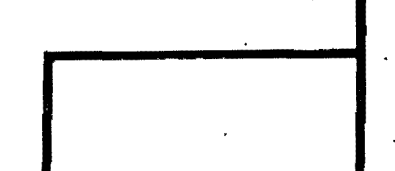

BEYOND PARENTAL CONTROL

OTHER.

ABANDONED

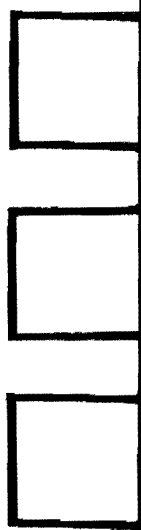

BURGLAIIY

SHOPLIFT

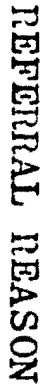

CRIMINAL MISCHIEF

UNAUTHORIZED VEHICLE USE

RUNATVAY

ROBBERY

TrESPASS 
APPENDIX L

MALES RESIDING AT THE CONMUNITY ATTENTION HOME FEVER TIAN THE MEDIAN (9) NURBBER OF DAYS COMPARED TO THE REASONS FOR THEIR REFERRAL

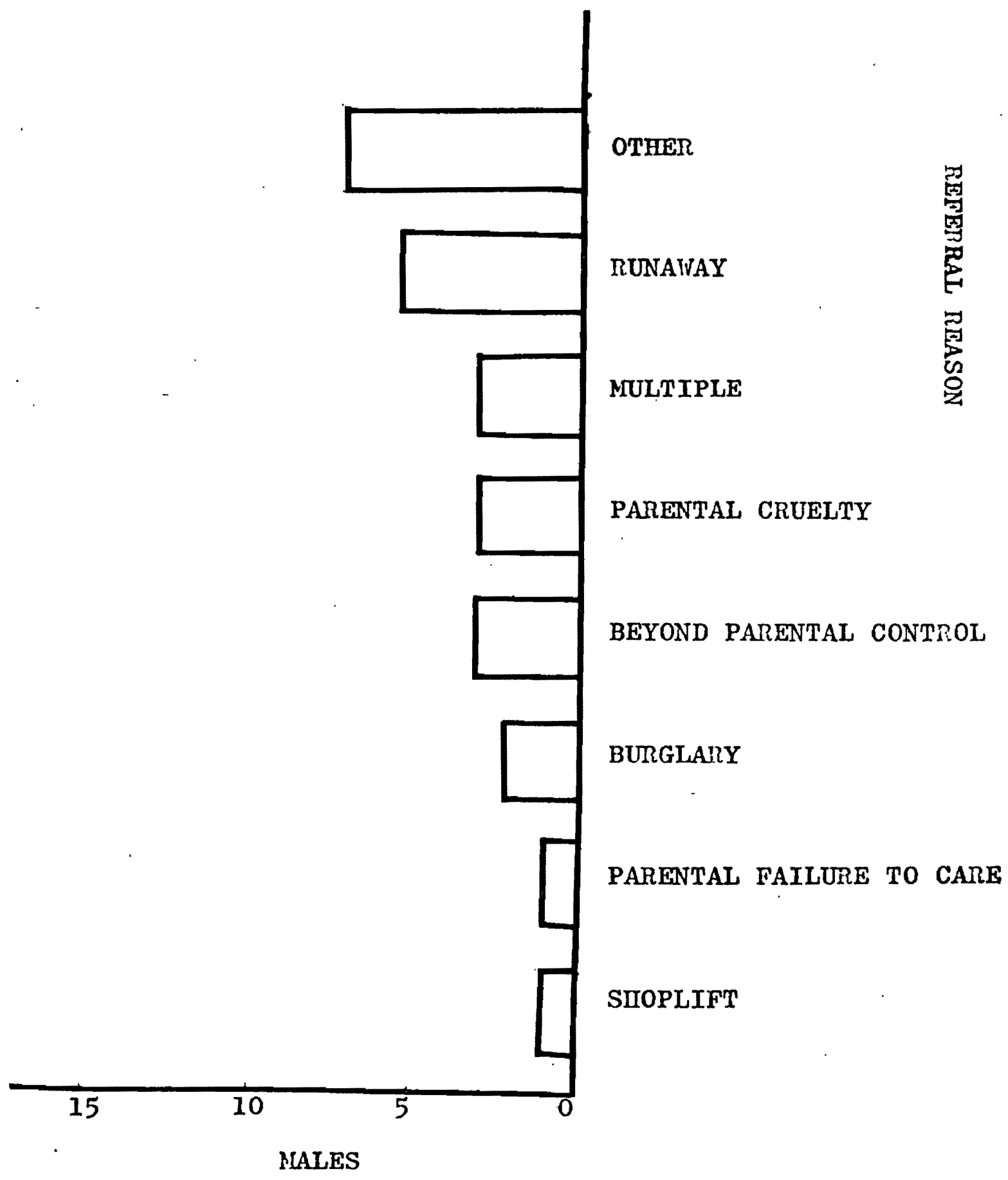


APPENDIX M

FENALES RESIDING AT THE COMNUNITY ATTENTION HOME MORE THAN THE MEDIAN $(\mathbf{1 1 . 5 )}$ NONBER OF DAYS COMPARED WITH THEIR REASONS FOR REFERRAL

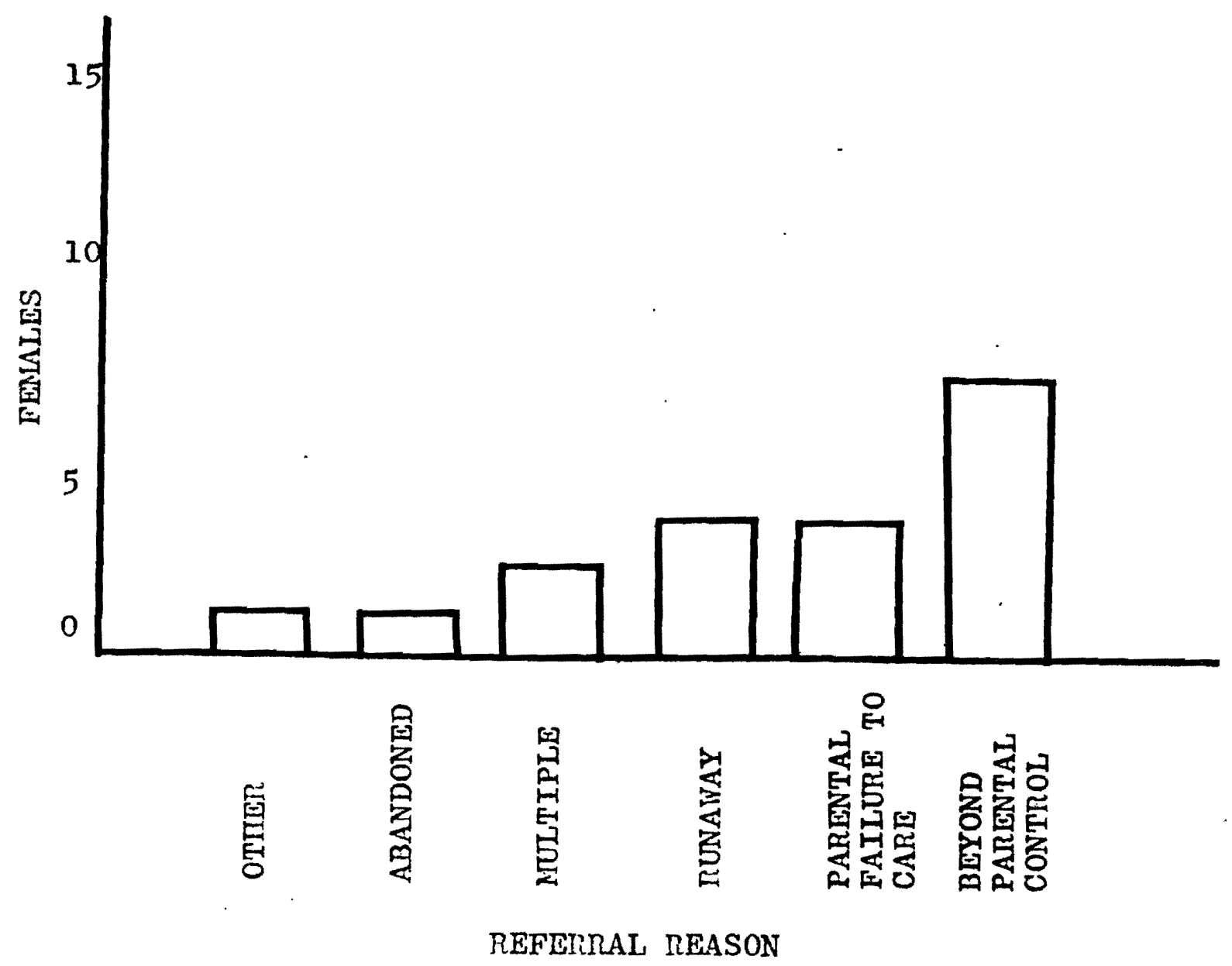


APPENDIX N

FENIALES RESIDING AT THE COMRINITTY ATTENTION HOME LESS THAN THE MEDIAN (11.5) NUMBER OF DAYS COMPARED TO THEIR REASONS FOR REFERRAL

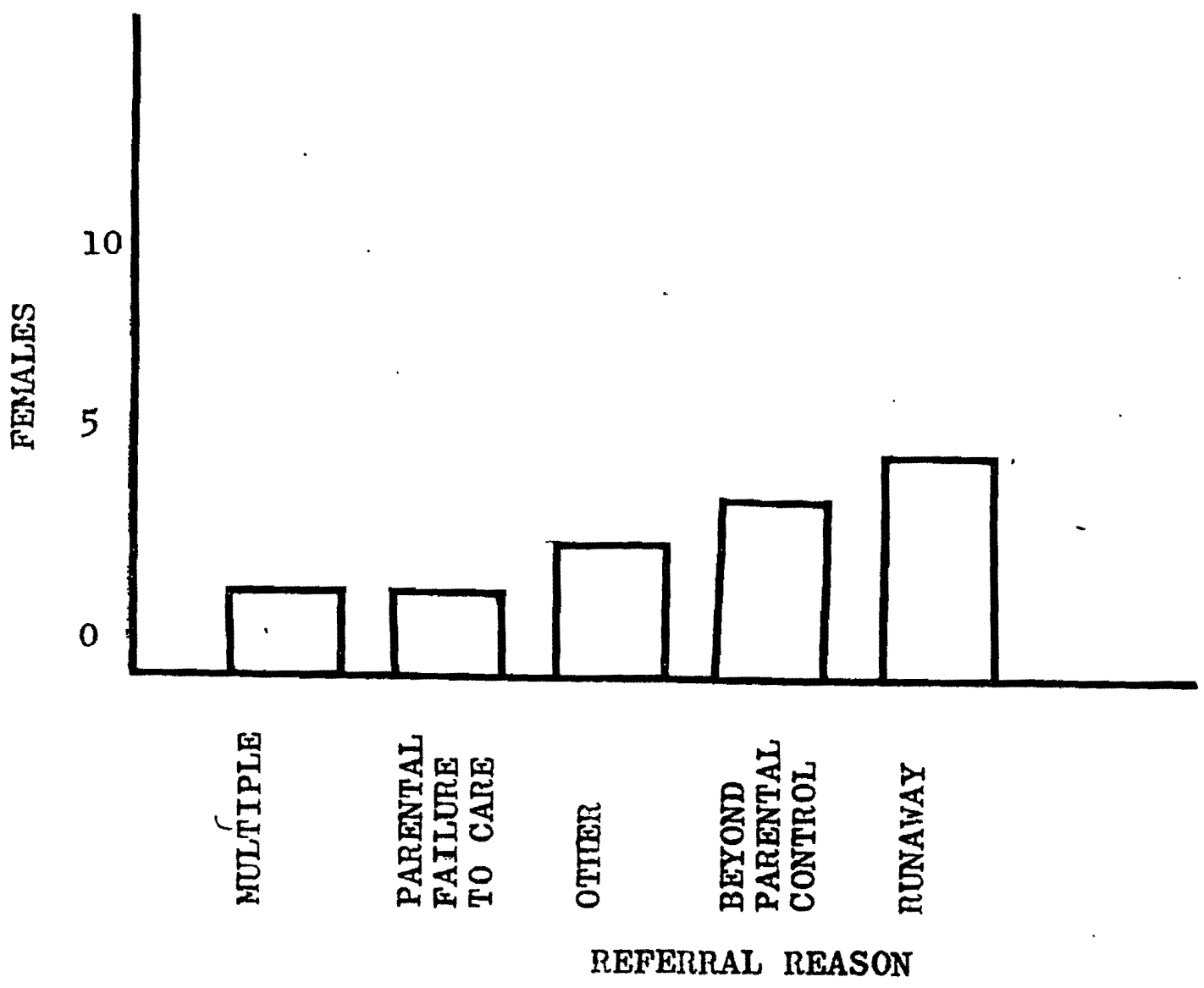


APPENDIX 0

NUMBER OF FEMLLE REFERRALS COHPARED WITH AGE IN YEARS

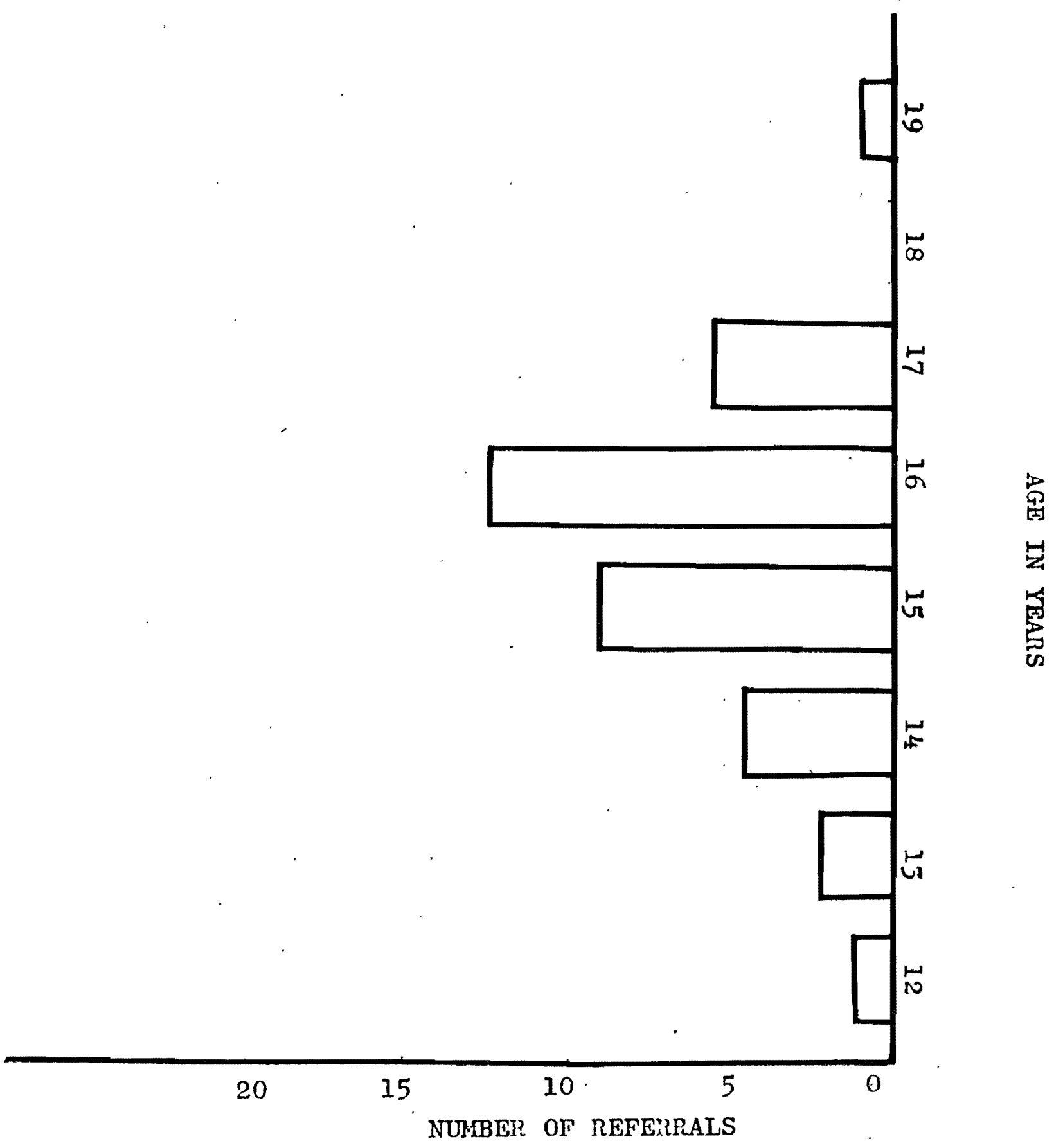


APPENDIX $P$

NURBEI MALE REFERRALS COMPARED WITI AGE IN YEARS

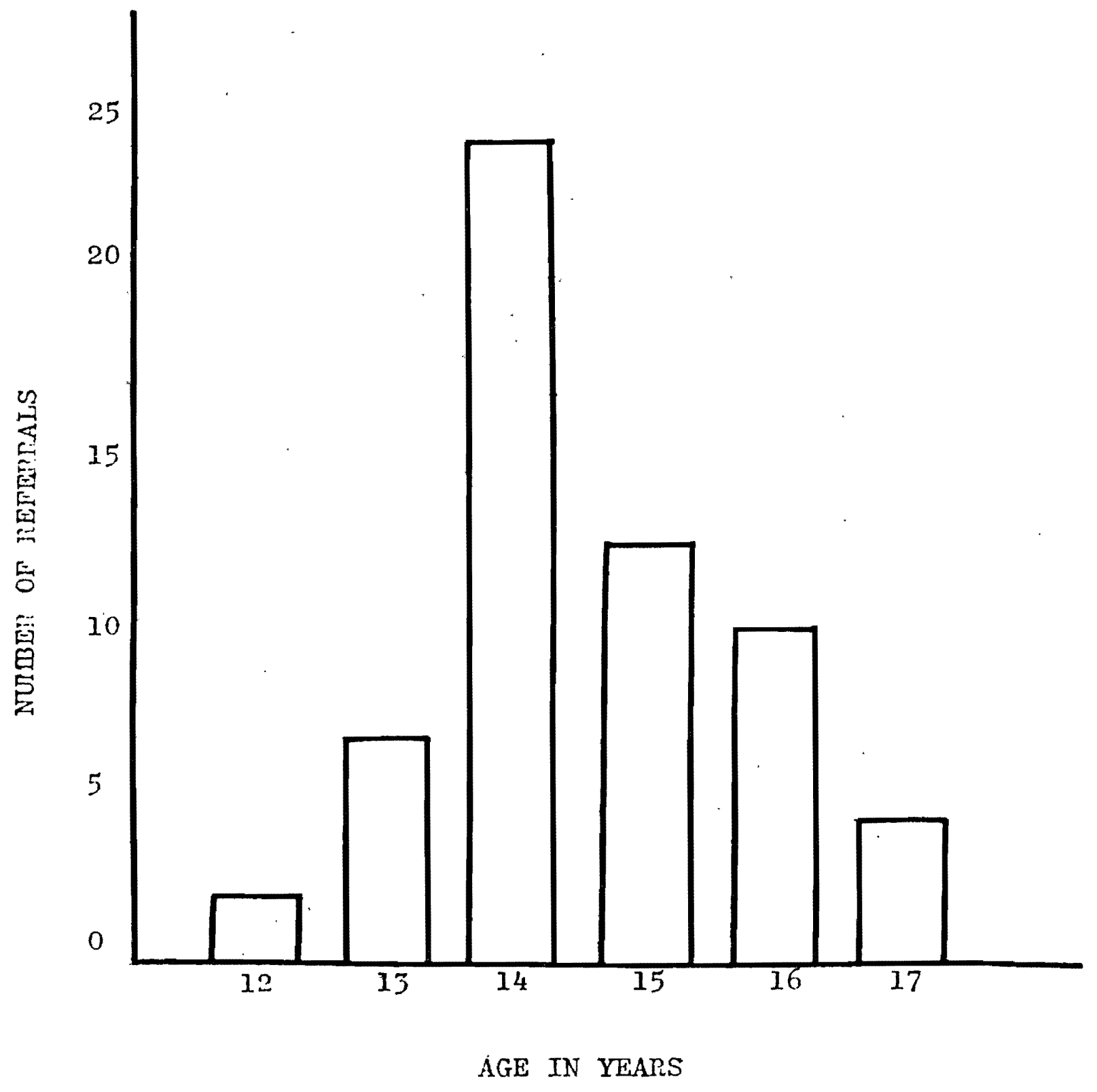


APPENDIX Q 
Case

Number:

Statistical Data Sheet

Date Received:

Date Discharged:

Sex: 01 Male.

02 Female

Age :

Ethnic Group: 01 White

02 Black

03 American Indian

04 Mexican-American

05 Other

Specify

Referral Source: 01 Children's Services Division

02 Juvenile Court Counselor

03 other

Specify

Placement Prior to Attention Home:

Known to Juvenile Court: 01 Yes 02 No

Detention Used: 01 Yes 02 No

Family Intact:

01 Yes

02 No

In School:

01 Yes

02 No

Employed:

01 Yes

02 No

Intake Goals:

01 Shelter Care

02 Evaluation for Placement

Goal Met: 01 Yes 02 No 
Prior Attention Ilome licsident: 01 Yes

$02 N o$

recommended Placement: 01 Oim Home

02 Foster Care

03 Groun Home Care

O' Institution

05 other

Specify

Description of the circustances nich led to referial at the Community Attention Ilore: 
APPENDIX 
lionth:

\section{Ionthly Statistical Data Shect Sumary}

In the spaces provided, total the ronth's responses fror: the individual Statistical Data Sheets.

Numer of cases continued from the previous month.

Nurber of new admissions.

Cases terminated this month.

Total number of children using this facility during this month.

Total child days provided.

Average Ien $\rightarrow$ th of stay.

Ethnic Group:

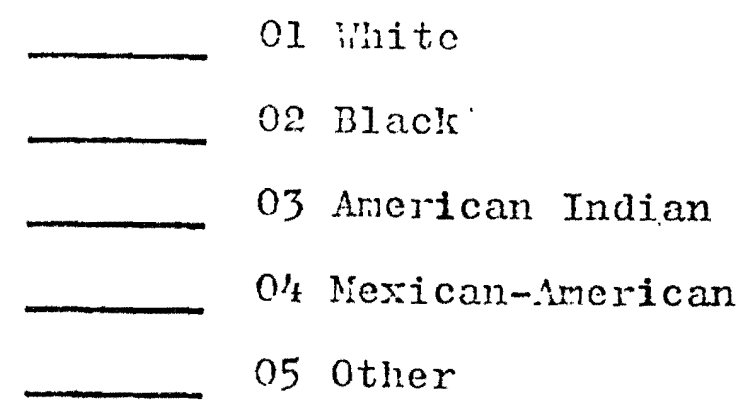

Inown to Juvenile Court:

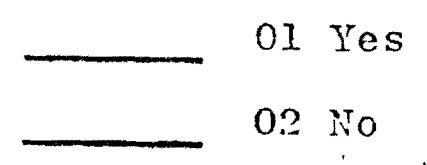

Detention Used:

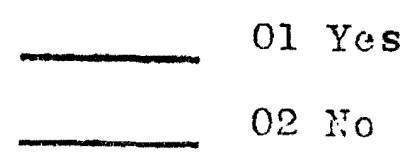

Farily Intact:

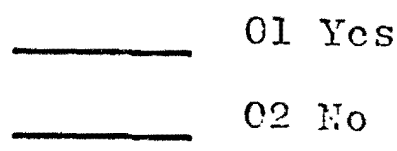


In School:

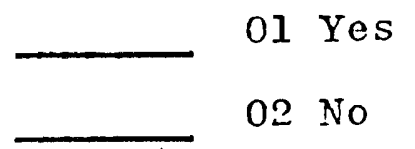

Employed:

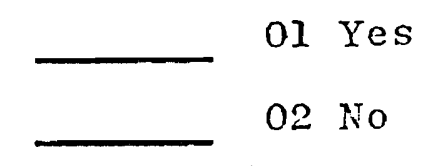

Intake Goals:

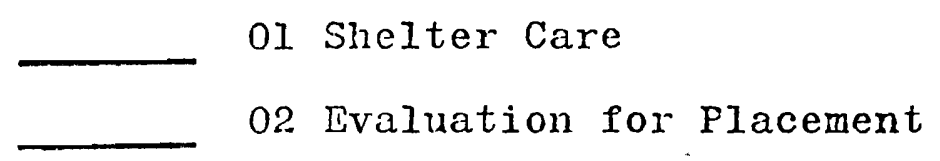

Goals Met:

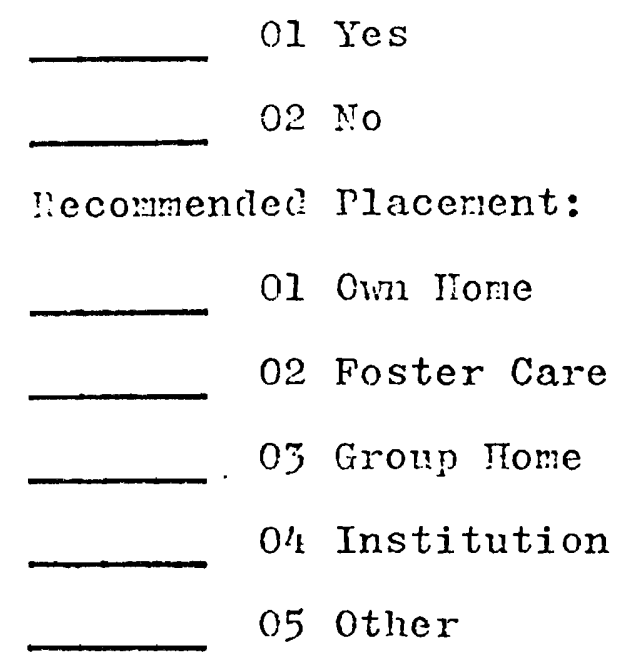

Actual Placement:

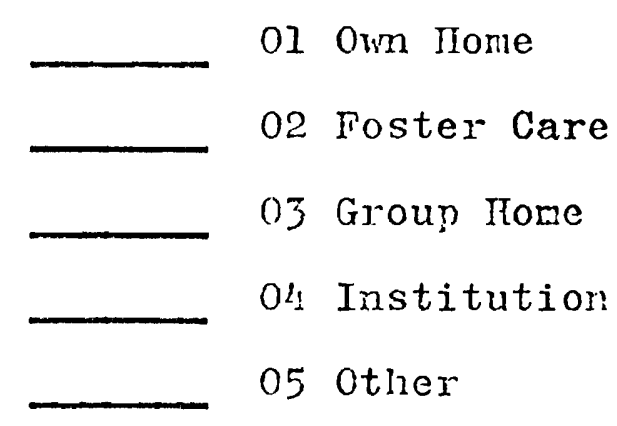


APPENDIX S 
Treatment Assessment Sheet

\section{Section I}

Almission Status

General:

Name:

Referral Code:

Planned Length of Stay:

School Status:

Caseworker/Counselor:

Parent/Guardian:

Address:

Phone Number:

other Family Niembers:

Address:

Phone Number:

Physical:

General Health:

Evident Illnesses:

Drug or Alcohol Use:

Prescribed Medications Used:

Allergies: 


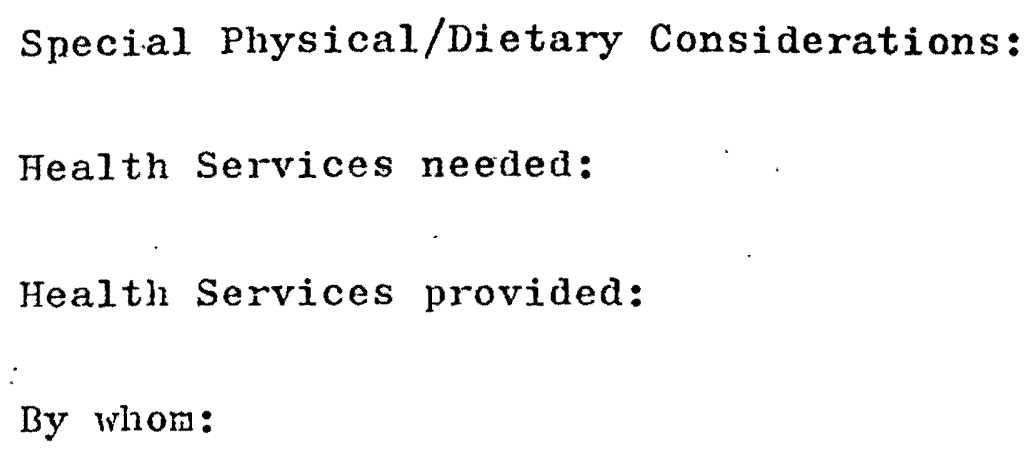

Attitude towards placement in Community Attention Ilome:

Attitude towards Community Attention Ilome placement reconmendation:

Special Considerations:

\section{Section II}

Necessary Personal Effects

Adequate upon entering the Community Attention Home?

If no, what was provided?

By whom?

\section{Section III}

\section{Child Behavior During Attention llome Stay}

School/Job:

inrolled in school: Not attending school: Employed: Not exployed: 
record days of school attendance:

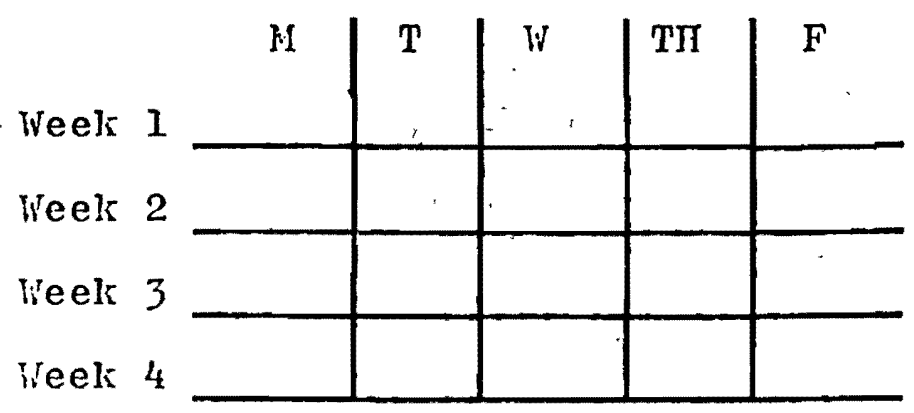

$\mathrm{X}=$ Attendance

$0=$ Non-attendance

$I=$ Excused absence

liecord days of job attendance:

\begin{tabular}{l|l|l|l|l} 
Week I & $\mathrm{T}$ & ir & TII & $\mathrm{F}$ \\
Week 2 & & & & \\
Week 3 & & & & \\
Week 4 & & & & \\
\hline
\end{tabular}

$X=$ Attendance

$0=$ Non-attendance

$I=$ Excused ahsence

Comments regarding school behavior (date entrics):

Comments regarding job behavior (date entries:

Compliance with Attention Ilome Rules:

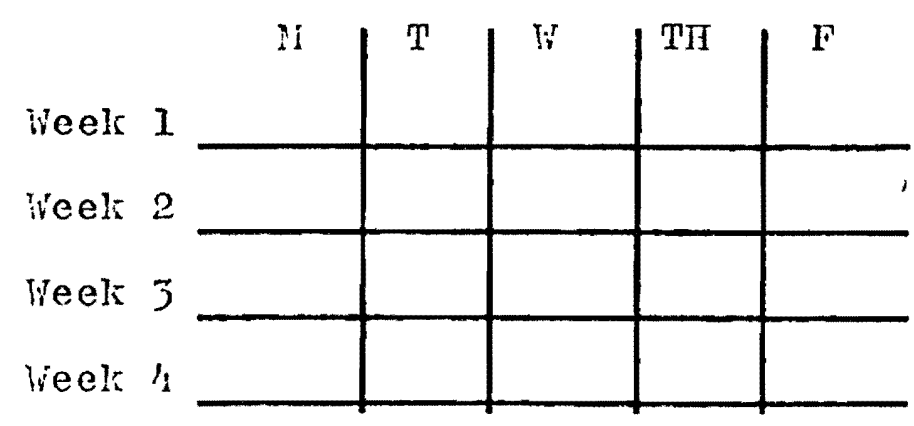

Record special problems (date entrics): 
Section IV

Describe contacts of relatives with houseparents (date entries):

Describe contacts of child and relatives (date entries): 


\section{$\underline{\text { Section V }}$}

Formal evaluation sessions by whom (i.e., Nental llealth, starfinrs, Children's Services Division, etc.):

Family sessions by whom (i.e., Attention Mome staff, Nental Health, Children's Services Division, ctc.): 
Individual sessions by whom (i.e., Mental Mealth, Children's Services Division, etc.):

Positive qualities of child (date entries): 
Describe Interactions with houseparents and other children (date entries): 
Describe interactions with peers (date entries): 


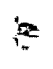

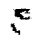

APPENDIX T

$\approx$

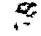

i

$i^{x}$

2

$?$

i

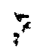

;

t.

$\div$

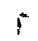

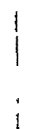


(Date)

To:

An outcome study of each child leaving the Community Attention Home, The Dalles, Oregon, is being conducted to see how that child fit the initial placement. Please fill out the attached form for the child indicated. It is important that forms be returned within 30 days as this information will enable the Community Attention Home to evaluate its assessment process and the appropriateness of its recommendation. Information provided will be treated as confidential and will be used by Community Attention Home staff only. Your cooperation in this matter is appreciated.

Sincerely,

$\angle \mathrm{s} /$

Edward Oppliger

Administrator

Community Attention Home, Inc. 2111 E. 7 th Place,

The Dalles, Oregon 97058

Phone number: 296-5826 


\section{Post-Placement Followup Sheet}

Full name of child

Nature of placement setting

Where initially placed

Address/phone number

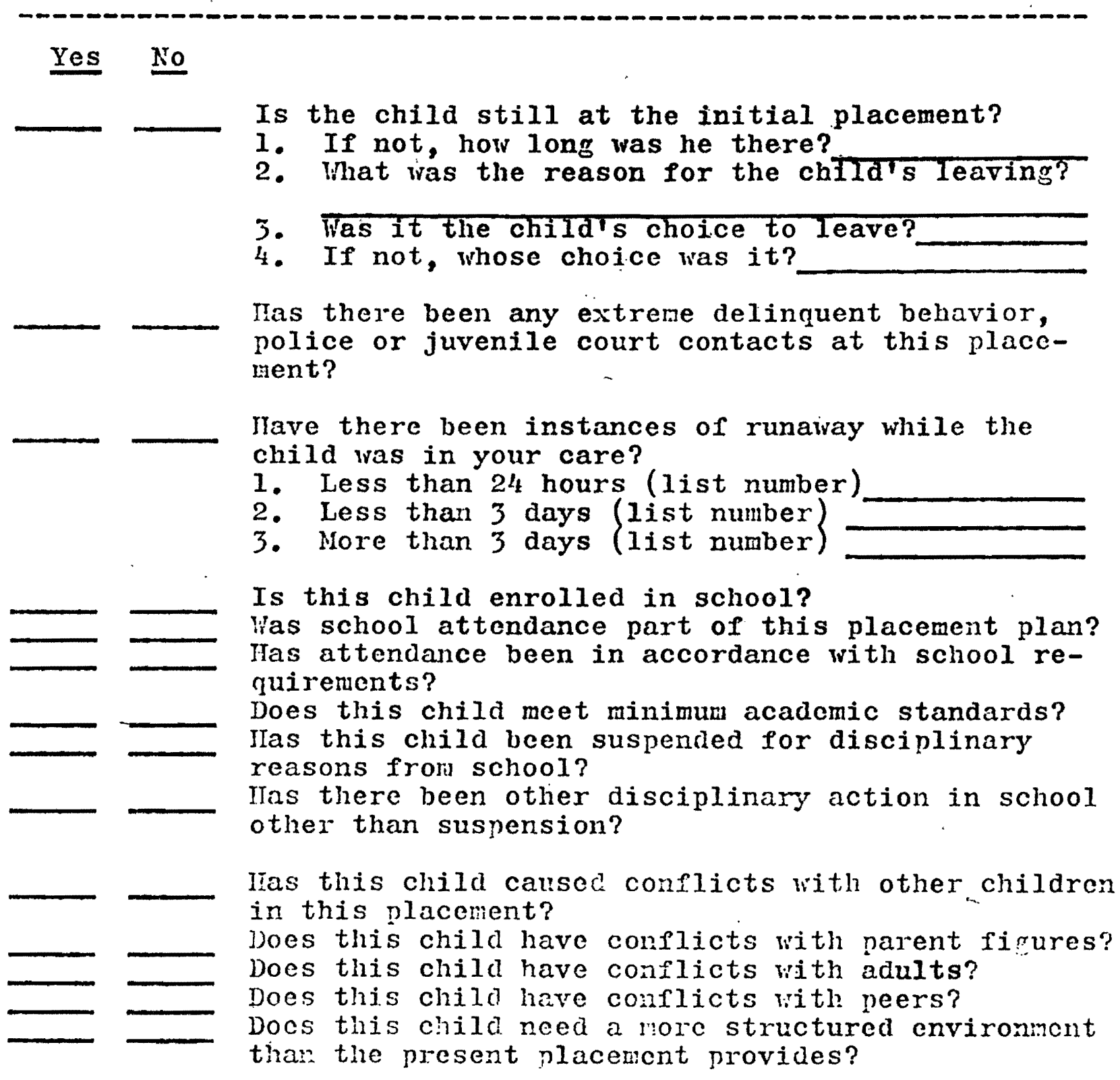


Were you satisfied with support from the child's caseworker?

Did social service agencies follow initial placement recommendations?

Has this case been terminated of involvement with such agencies?

1. If so, why? 